\title{
Article
}

\section{The Effects of Sulphuric Acid and Sodium Chloride Agglomeration and Curing on Chalcopyrite Leaching}

\author{
Víctor Quezada ${ }^{1,2, *(0)}$, Antoni Roca ${ }^{1}$, Oscar Benavente ${ }^{2}$, Montserrat Cruells ${ }^{1}$ and Evelyn Melo ${ }^{2}$ \\ 1 Departamento de Ciencia de los Materiales y Química Física, Universitat de Barcelona, \\ 08028 Barcelona, Spain; roca@ub.edu (A.R.); mcruells@ub.edu (M.C.) \\ 2 Departamento de Ingeniería Metalúrgica y Minas, Universidad Católica del Norte, \\ Antofagasta 1270709, Chile; obenaven@ucn.cl (O.B.); emelo@ucn.cl (E.M.) \\ * Correspondence: vquezada@ucn.cl; Tel.: +56-552651024
}

Citation: Quezada, V.; Roca, A.; Benavente, O.; Cruells, M.; Melo, E. The Effects of Sulphuric Acid and Sodium Chloride Agglomeration and Curing on Chalcopyrite Leaching Metals 2021, 11, 873. https://doi.org/ $10.3390 /$ met11060873

Academic Editors: Jean-François Blais and Anna H. Kaksonen

Received: 10 March 2021

Accepted: 25 May 2021

Published: 27 May 2021

Publisher's Note: MDPI stays neutral with regard to jurisdictional claims in published maps and institutional affiliations.

Copyright: (c) 2021 by the authors. Licensee MDPI, Basel, Switzerland. This article is an open access article distributed under the terms and conditions of the Creative Commons Attribution (CC BY) license (https:// creativecommons.org/licenses/by/ $4.0 /)$

\begin{abstract}
An option to improve the leaching efficiency of chalcopyrite is pretreatment prior to leaching. Pretreatment variables, such as the curing time and the addition of chloride, can increase the kinetics of copper extraction, particularly for sulphide ores. However, there has been little research on the topic. The reactions that govern this phenomenon have not been clearly identified. In this study, the effects of sulphuric acid and sodium chloride agglomeration and curing on chalcopyrite leaching were evaluated at various temperatures: $25,50,70$, and $90^{\circ} \mathrm{C}$. The pretreated ore and leach residues were characterised by $\mathrm{X}$-ray diffraction, scanning electron microscopy, and reflected light microscopy. Under the conditions of $15 \mathrm{~kg} / \mathrm{t}$ of $\mathrm{H}_{2} \mathrm{SO}_{4}, 25 \mathrm{~kg} / \mathrm{t}$ of NaCl , and 15 days of curing time (as pretreatment), the following products were identified: $\mathrm{CuSO}_{4}, \mathrm{NaFe}_{3}\left(\mathrm{SO}_{4}\right)_{2}(\mathrm{OH})_{6}, \mathrm{Cu}_{2} \mathrm{Cl}(\mathrm{OH})$, and $\mathrm{S}^{0}$. Increasing the curing time and leaching temperature increased copper leaching. The copper

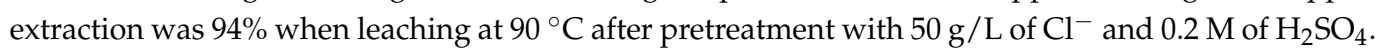
Elemental sulphur, jarosite, and copper polysulphide $\left(\mathrm{CuS}_{2}\right)$ were detected in the leaching residues.
\end{abstract}

Keywords: pretreatment; curing time; chalcopyrite; chloride; leaching

\section{Introduction}

In the transition of Chile from a developing economy to a developed economy, mining plays a key role in sustaining the economy with care to minimise the ecological impact on the environment and to promote social growth [1]. Innovation and new mineral processing alternatives are essential to maintaining copper production [2,3].

According to the Chilean Copper Commission (Cochilco), 27.3\% of Chilean copper is produced using hydrometallurgy [4]. However, copper production by hydrometallurgy is expected to decrease $11.6 \%$ by 2029 owing to the depletion of the copper oxide ores in Chilean copper deposits. As a consequence, copper producers in Chile are switching to use concentration processes due to the mineralogy shifting to primary copper sulphidesmainly chalcopyrite. Chalcopyrite $\left(\mathrm{CuFeS}_{2}\right)$ is the most abundant copper-bearing resource, accounting for more than $70 \%$ of global copper reserves [5].

One of the challenges for hydrometallurgy is the treatment of refractory copper minerals under conventional leaching conditions, such as black copper oxides [6,7] and primary sulphides (mainly chalcopyrite $\left.\left(\mathrm{CuFeS}_{2}\right)\right)[8,9]$. The slow dissolution kinetics of chalcopyrite are due to the formation of a product layer that inhibits the contact of the solution with the mineral [10]. Many researchers have studied this layer [11-13].

Several leaching media have been proposed to improve the copper extraction and dissolution kinetics from copper sulphide ores, including chloride [14-16], nitrate [17,18], and ammonia [19-22]. Furthermore, the bioleaching alternative has also been studied [23-27]. Chloride media are some of the most widely studied and effective media due to the reactivity of the $\mathrm{Cl}^{-}$with sulphide ores [28]. Although chloride generates corrosive media, there are processes that successfully use chloride at an industrial scale $[29,30]$. 
Leaching pretreatments and, particularly, curing have been identified as beneficial in the dissolution of copper sulphide minerals [18,31-33]. According to Dhawan et al. [34], curing time generates a homogeneous distribution of acid in the mineral bed, increases the kinetics of copper dissolution, and inhibits the dissolution of aluminium-silicate minerals (acid consumers). However, [35] indicated that there has been limited research into the effect of curing time on the dissolution of copper ores. In recent years, the effect of acid curing has been studied mainly for chalcopyrite in chloride media. Most studies on pretreatments (especially curing time) have been conducted on chalcopyrite $[18,31,32]$.

The results obtained by Quezada et al. [33] point to the benefits of curing time for leaching chalcocite/covellite minerals in columns. The authors demonstrated that an extended curing period, together with the addition of sulphuric acid and chloride, enhanced the dissolution rate of a secondary copper sulphide ore. They also found that it was possible to obtain a $72 \% \mathrm{Cu}$ extraction when the ore was agglomerated and cured for 50 days in chloride media. According to the variance analysis, the curing time made a significantly more important contribution to the copper extraction $(92.37 \%)$ than did the chloride concentration $(7.05 \%)$ under the studied conditions. Similar results were obtained with the column leaching of chalcopyrite ore with a $\mathrm{P}_{80}$ of $5 \mathrm{~mm}$ achieving a maximum copper extraction of $43 \%$ using chloride media at room temperature and 100 days of curing [32].

Cerda et al. [31] studied the role of temperature in pretreatment [31]. The authors demonstrated that a copper extraction of $93 \%$ was obtained when the ore (mainly chalcopyrite) was treated with $90 \mathrm{~kg}$ of $\mathrm{Cl}^{-} / \mathrm{t}$ ore, with 40 days of curing at $50{ }^{\circ} \mathrm{C}$ in flask leaching. Cerda el al. [31] proposed pretreatment reactions that considered the effect of $\mathrm{Cu}^{2+}$ and $\mathrm{Cl}^{-}$ on chalcopyrite, generating covellite and $\mathrm{CuCl}$ as products (Table 1, Reaction (1)). Covellite reacts in the presence of $\mathrm{H}^{+}$and $\mathrm{O}_{2}$. According to Reaction (2), covellite does not generate $\mathrm{Cu}^{2+}$, necessary for the reaction of chalcopyrite (Reaction (1)). However, chalcocite may be a source of $\mathrm{Cu}^{2+}$ given the proposed reaction generated in the pretreatment (Table 1, Reaction (3)). $\mathrm{Cu}^{2+}$ can also be added to the solution. The corresponding Gibbs energy values are negative; therefore, these reactions are thermodynamically feasible (See Table 1).

Table 1. Proposed reactions for copper sulphide pretreatment (adapted from [31]).

\begin{tabular}{lccc}
\hline $\mathbf{N}^{\circ}$ & Reactions & $\Delta \mathbf{G ~ 2 5}{ }^{\circ} \mathbf{C}(\mathbf{k c a l} / \mathbf{m o l})$ & $\Delta \mathbf{G} \mathbf{5 0}{ }^{\circ} \mathbf{C}(\mathbf{k c a l} / \mathbf{m o l})$ \\
\hline$(1)$ & $\mathrm{CuFeS}_{2}+2 \mathrm{Cu}^{2+}+2 \mathrm{Cl}^{-} \rightarrow 2 \mathrm{CuCl}+\mathrm{CuS}+\mathrm{Fe}^{2+}+\mathrm{S}$ & -15.6 & -16.4 \\
$(2)$ & $2 \mathrm{CuS}+4 \mathrm{H}^{+}+\mathrm{O}_{2}+2 \mathrm{Cl}^{-} \rightarrow 2 \mathrm{CuCl}^{+}+2 \mathrm{H}_{2} \mathrm{O}+2 \mathrm{~S}$ & -55.2 & -53.2 \\
$(3)$ & $2 \mathrm{Cu}_{2} \mathrm{~S}+4 \mathrm{H}^{+}+\mathrm{O}_{2} \rightarrow 2 \mathrm{CuS}+2 \mathrm{Cu}^{2+}+2 \mathrm{H}_{2} \mathrm{O}$ & -68.1 & -65.9 \\
\hline
\end{tabular}

This research evaluated the effects of sulphuric acid and sodium chloride agglomeration and curing on the chalcopyrite leaching efficiency at various temperatures. The agglomerated ore and leaching residues were characterised using $\mathrm{X}$-ray diffraction (XRD), scanning electron microscopy (SEM), reflected light microscopy, and a stereographic zoom microscope.

\section{Materials and Methods}

\subsection{Chalcopyrite Ore}

Chalcopyrite was obtained from an operating plant in Antofagasta, Chile. The sample was initially crushed by a jaw crusher, followed by a secondary and tertiary cone crusher, and it was then dry milled in a ball mill to $-38+25 \mu \mathrm{m}$. The mineral particles were reduced in size with a closed crushing and grinding circuit.

The chemical composition of the screened sample was determined using inductively coupled plasma-optical emission spectroscopy (ICP-OES, Optima 8300, Perkin Elmer, Waltham, MA, USA). Before ICP-OES analysis, the solid sample was digested using a $1 \mathrm{~g}$ sample in $20 \%$ aqua regia solution and reached the boiling point. 
Mineralogical data were obtained through X-ray diffraction (XRD) analysis using a diffractometer (PANalytical X'Pert PRO MPD Alpha1, Malvern, UK), operated from $4^{\circ}$ to $100^{\circ} 2 \theta$, at $45 \mathrm{kV}, 40 \mathrm{~mA}, \mathrm{~K} \alpha 1.54 \AA$, a step size of $0.017^{\circ}$, and a time per step of $150 \mathrm{~s}$. X-ray diffractogram sand crystalline phase identification was interpreted using the software X'pert HighScore Plus v.3.0e (PANalytical, Almelo, Netherland).

Qemscan analysis was performed using a Model Zeiss EVO 50 (Zeiss, Oberkochen, Germany), with Bruker AXS XFlash 4010 detectors (Bruker, Billerica, MA, USA) and Software iDiscover 5.3.2.501 (FEI Company, Brisbane, Australia). Additionally, a reflected light microscope (Zeiss, Axiovert 100, Milan, Italy) was used. A Stereographic Zoom Microscope (Motic, SMZ-168, Richmond, British Columbia, Canada) was used for a superficial visual analysis. The microscope had a halogen fibre optic illuminator light box (Motic, MLC-150C, Xiamen, China). Finally, morphological characterisation was performed using a scanning electron microscope (SEM, JEOL J-7100F, Tokyo, Japan), operated at $20 \mathrm{kV}$ under high vacuum conditions (Emitech K-950X, Lohmar, Germany) coupled with an energydispersive X-ray spectroscopy (EDS) microanalysis system (Oxford Instruments INCA, Oxfordshire, UK). Mineral samples were coated with a thin layer of carbon to improve their conductivity. A carbon source, in the form of a rod, was mounted in a vacuum system between two high-current electrical terminals. When the carbon source was heated to its evaporation temperature, a fine stream of carbon was deposited onto specimens, before SEM characterisation.

\subsection{Curing Experiments}

Two grams of chalcopyrite sample was used in each curing test. The mineral was agglomerated on an impermeable plastic surface by manually mixing the mineral with the solution. The samples were agglomerated with a solution of $15 \mathrm{~kg} / \mathrm{t}$ of $\mathrm{H}_{2} \mathrm{SO}_{4}$ and $25 \mathrm{~kg} / \mathrm{t}$ of NaCl using a solid/liquid ratio of 10/1 (mass/volume), namely using $0.1 \mathrm{~mL}$ of solution per $1 \mathrm{~g}$ of ore (Figure 1). After agglomeration, the samples were placed on watch glasses, covered with a protective film (thermoplastic) and cured in the dark at room temperature for 15 days. The cured samples were used for mineralogical characterisation and leaching tests. After the curing time, briquettes were formed for the mineralogical characterisation using a stereographic microscope, reflected light microscope, $\mathrm{XRD}$, and SEM. The briquettes were prepared and polished without contact with water to avoid dissolving the soluble phases. Finally, cured samples were also used to evaluate the effect of pretreatment on the chalcopyrite dissolution.

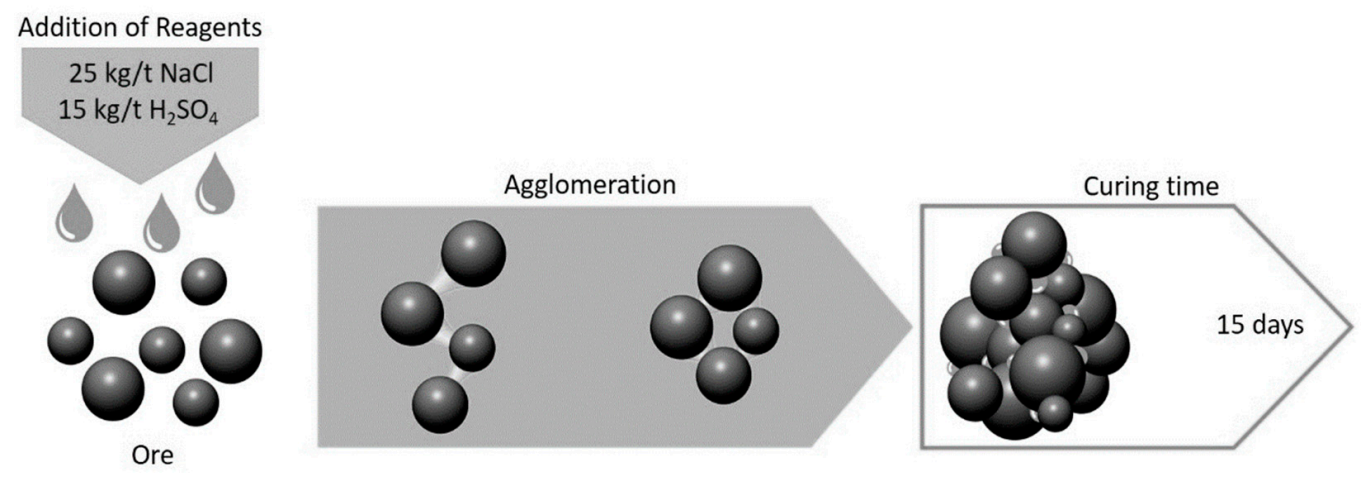

Figure 1. Agglomeration and curing procedure.

\subsection{Leaching Test}

The pretreated and untreated chalcopyrite samples were leached in $200 \mathrm{~mL}$ (Figure 2)

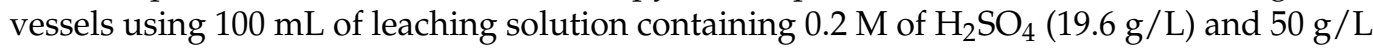
of $\mathrm{Cl}$ ions. The vessels were agitated using a hot plate magnetic stirrer IKA C-MAG HS7 at $200 \mathrm{~min}^{-1}$. When the solution reached desired temperatures of $25,50,70$, and $90^{\circ} \mathrm{C}$ $\left( \pm 1^{\circ} \mathrm{C}\right)$, the $2 \mathrm{~g}$ sample of cured or noncured ore was added to the solution, and leaching 
was carried for a period of $48 \mathrm{~h}$. During the leaching process, the holes in the vessel lid were not covered. Evaporation loss was compensated by adding deionised water.

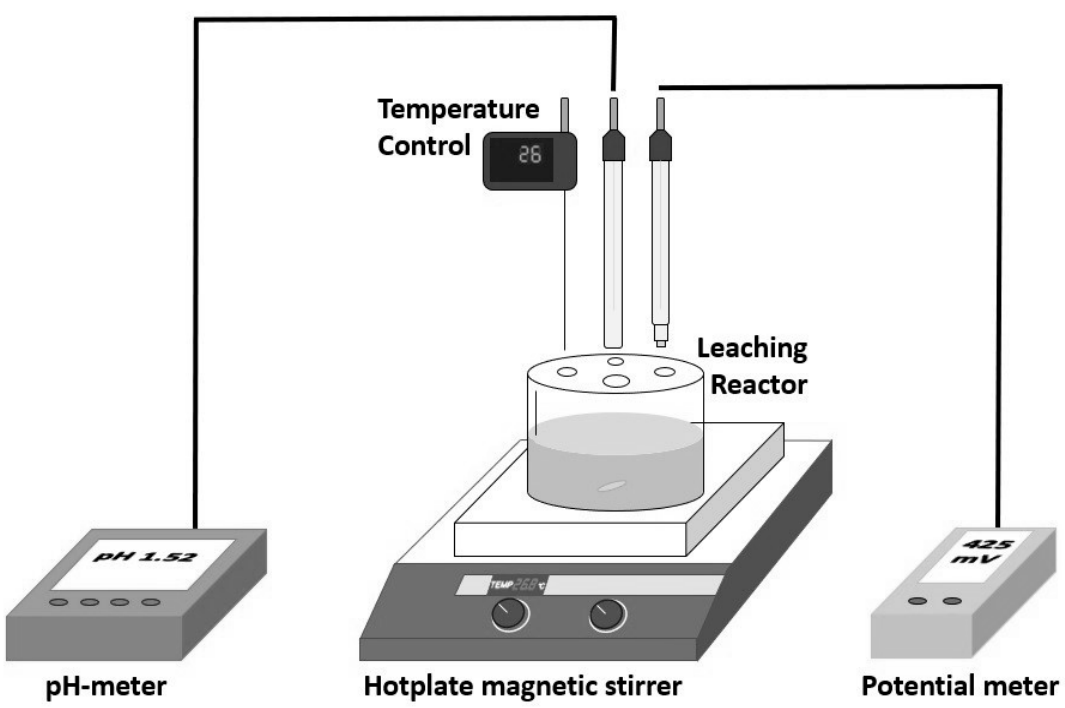

Figure 2. Scheme of the magnetic stirrer leaching system.

Solution samples ( $3 \mathrm{~mL}$ aliquots) were periodically withdrawn for chemical analysis. The samples were filtered $(0.2 \mu \mathrm{m})$, and the metal concentrations in the filtrate were determined by inductively coupled plasma-optical emission spectrometry (ICP-OES). The $\mathrm{pH}$ and redox potential were regularly measured (only during sampling time) using a Crison pH meter (Crison Instruments S.A, Basic 20, Barcelona, Spain). The $\mathrm{pH}$ measurements were carried out by using a Crison electrode, series 52 03, with a ceramic diaphragm and a reference element of $\mathrm{Ag} / \mathrm{AgCl}$ crystals. The oxidation-reduction potential (ORP) measurements were carried out by using a Crison electrode, series 53 61, with platinum as the metal indicator and a silver wire coated by $\mathrm{AgCl}$ as the reference element. All solution potentials were converted to values against the standard hydrogen electrode (SHE). The solid residues from the leaching experiments were analysed using XRD and SEM.

\section{Results and Discussion}

\subsection{Chalcopyrite Ore Characteristics}

The sample used in this study was characterised in a previous study by the same authors [36]. The chemical composition of the sample was $28.5 \% \mathrm{Cu}, 22.8 \% \mathrm{Fe}$, and $29.7 \% \mathrm{~S}$ (main elements). Other elements were detected in small percentages, namely, $\mathrm{Na}(0.220 \%)$, $\mathrm{Ca}(0.180 \%)$, and $\mathrm{Zn}(0.0800 \%)$. Chemical characterisation showed that insoluble residues represented $21.0 \%$ of the total mass, which suggests the presence of quartz and some silicates as insoluble phases in the sample.

Figure 3 (X-ray diffractogram) shows that the sample was mainly composed of chalcopyrite, together with quartz, pyrite, and chalcanthite. Sulphur can be associated with chalcopyrite and other species, such as chalcocite, covellite, and pyrite. Table 2 shows the mineralogical composition obtained via Qemscan analysis. The main species were chalcopyrite (73.7\%), followed by quartz (16.3\%) and covellite (1.80\%). According to the Qemscan analysis, quartz was present at $16.3 \%$, which is consistent with the insoluble residue product of the chemical characterisation $(21.0 \%)$.

SEM analysis showed the dominance of chalcopyrite, quartz, and copper sulphate in the initial sample (Figure 4). The presence of chalcanthite was measured by washing the sample with water, and a copper extraction of $9 \%$ was obtained. 


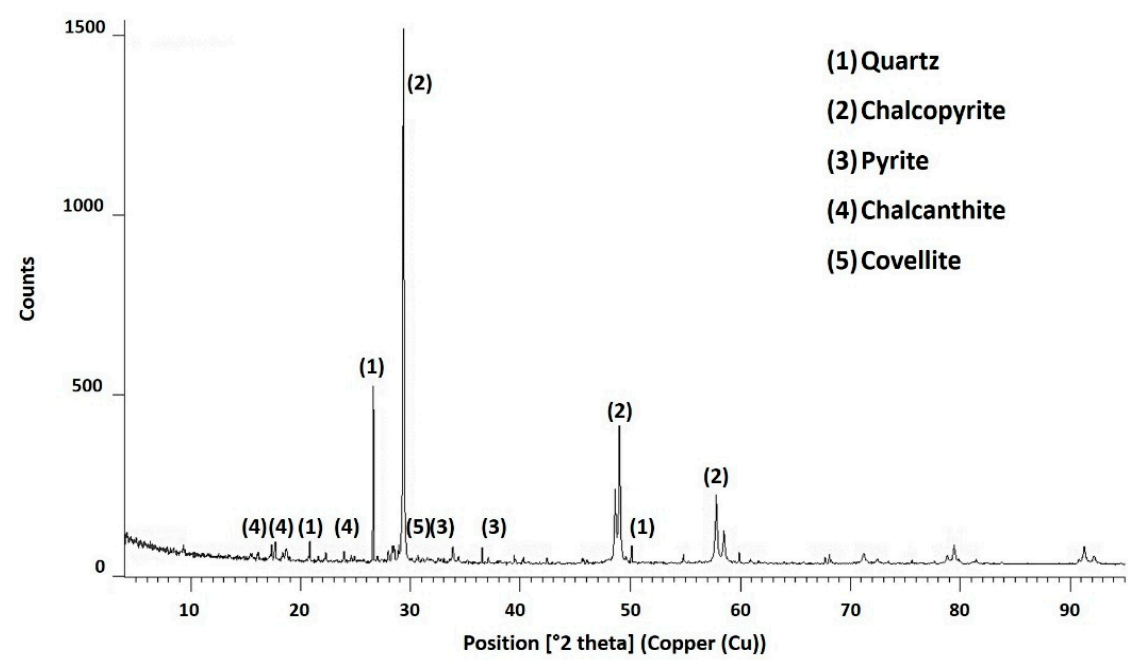

Figure 3. X-ray diffraction pattern of the initial sample [36].

Table 2. Main minerals in the chalcopyrite ore (mass in \%) based on Qemscan analysis [36].

\begin{tabular}{cc}
\hline Mineral & Mass \% \\
\hline Chalcopyrite & 73.7 \\
Quartz & 16.3 \\
Covellite & 1.80 \\
K-Feldspar (orthoclase, anorthoclase) & 1.80 \\
Pyrite & 1.30 \\
Molybdenite & 1.00 \\
Alunite & 0.900 \\
Other gangue & 2.60 \\
Other Cu minerals & 0.600 \\
\hline
\end{tabular}

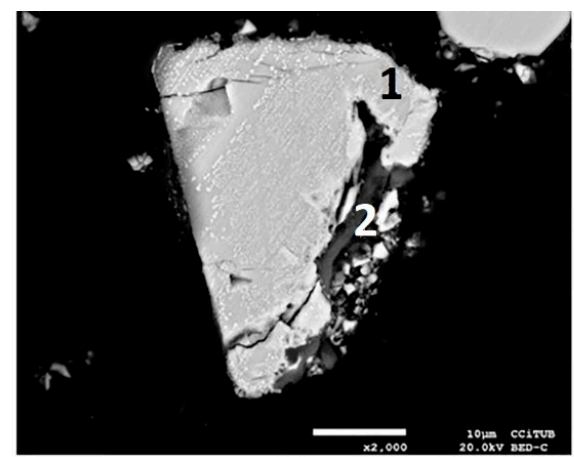

(a)

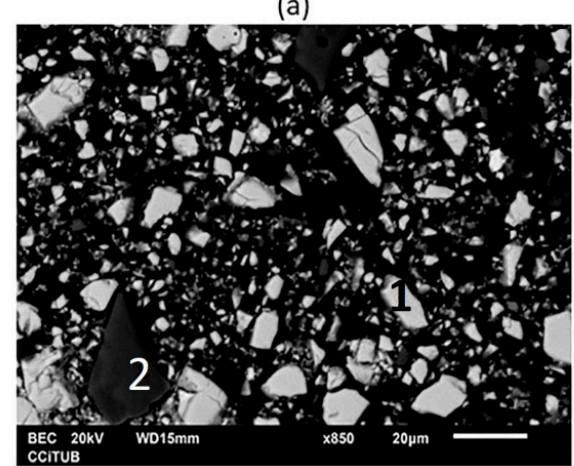

(c)

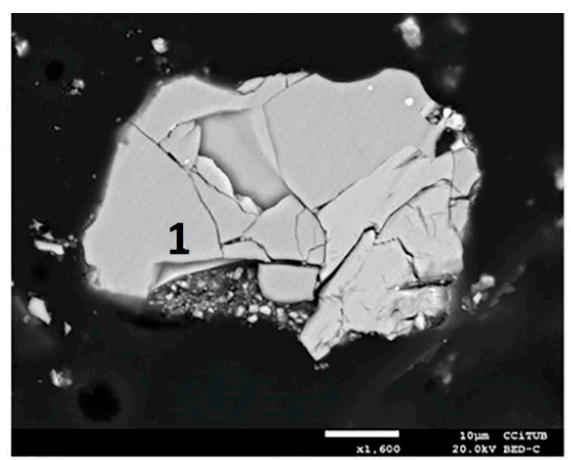

(b)

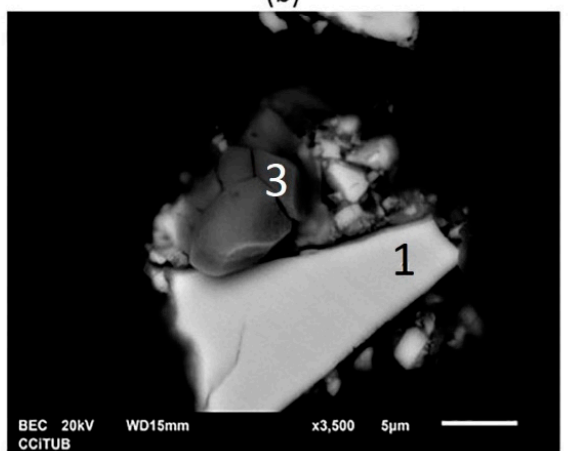

(d)

Figure 4. SEM image of the initial sample at various magnifications $(\mathbf{a}) \times 2.000,(\mathbf{b}) \times 1.600,(\mathbf{c}) \times 850$ and $(\mathbf{d}) \times 3500$. 1: chalcopyrite, 2: quartz, and 3: copper sulphate (chalcanthite) [36]. 


\subsection{Characteristics of Cured Ore Samples}

In a previous work [36], the authors obtained a copper extraction of $22.66 \%$ with a pretreatment using $25 \mathrm{~kg} / \mathrm{t}$ of NaCl and $15 \mathrm{~kg} / \mathrm{t}$ of $\mathrm{H}_{2} \mathrm{SO}_{4}$ with 15 days of curing time.

The pretreatment products obtained (agglomerated solids) were characterised to propose a mechanism for the pretreatment of chalcopyrite. The briquette formed and used for characterisation was observed using a stereographic microscope (Figure 5).

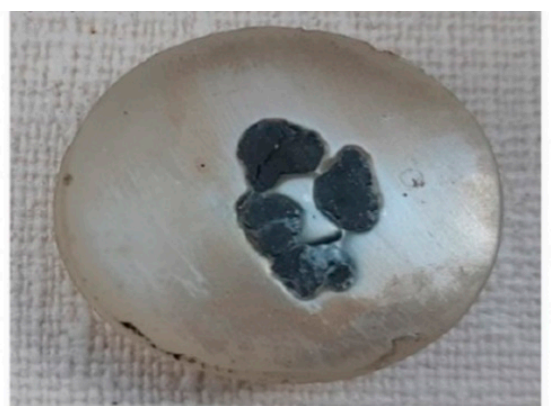

(a)

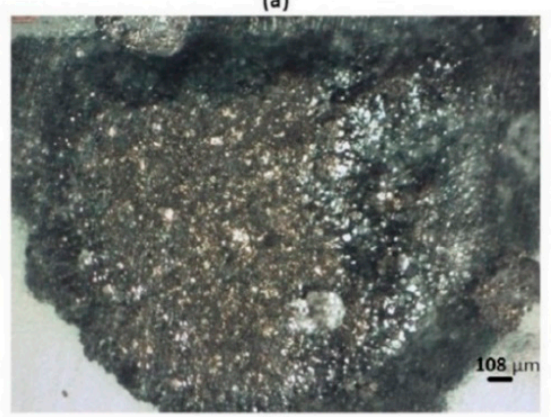

(c)

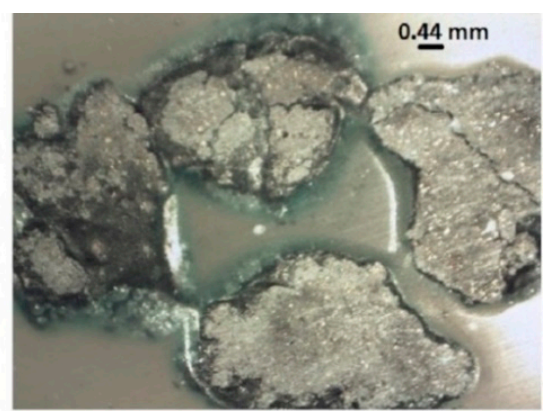

(b)

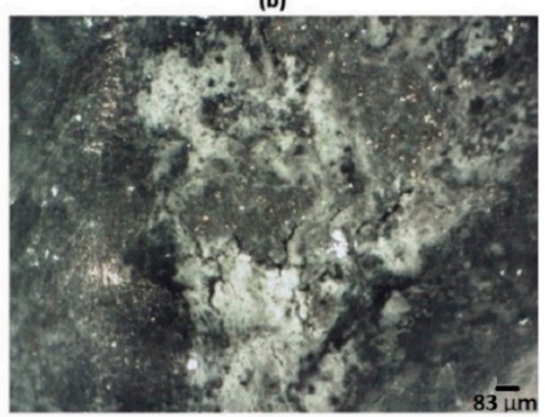

(d)

Figure 5. Images of the agglomerates obtained with a stereographic microscope. In (a) initial briquette, (b) at a magnification of $\times 0.75$ and $(\mathbf{c}, \mathbf{d})$ at $\times 5$.

The agglomerated ore samples were characterised with a reflected light microscope to detect possible changes in the mineral composition as a result of the pretreatment. Several cracks were observed on the surface of the chalcopyrite particles as products of the pretreatment (Figure 6a). The cracks and products generated in Figure 6a suggest that they were caused by the reactivity of the system and chemical crushing. Figure $6 \mathrm{~b}$ shows an area with the eventual formation of copper sulphate or a copper-chloride complex (green and white area). The formation of these products was subsequently confirmed by SEM and $\mathrm{X}$-ray analysis.

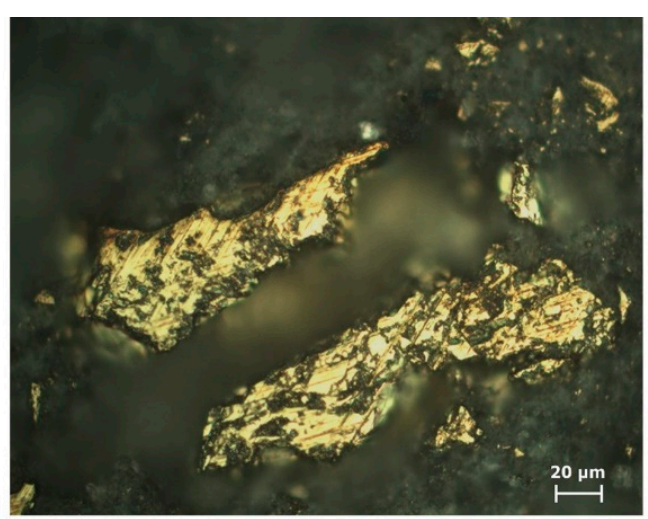

(a)

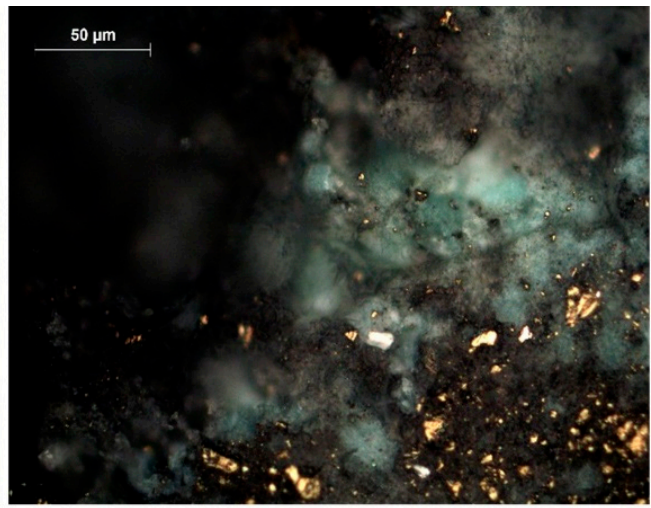

(b)

Figure 6. Reflected optical microscope images of the pretreatment products at a magnification of $\times 50(\mathbf{a}, \mathbf{b})$. 
The copper extraction achieved, using $15 \mathrm{~kg} / \mathrm{t}$ of $\mathrm{H}_{2} \mathrm{SO}_{4}, 25 \mathrm{~kg} / \mathrm{t}$ of NaCl , and 15 days of curing, was $22.66 \%$ before leaching, evidencing the formation of new soluble phases. Figure $6 \mathrm{~b}$ suggests the formation of a new soluble phase, such as $\mathrm{CuCl}$, as suggested by [31], while the formation of a $\mathrm{CuCl}_{2}$ complex is also possible in nitrate and chloride media according to [18] (Reaction (4)).

$$
\begin{gathered}
2 \mathrm{CuFeS}_{2}+10 \mathrm{H}_{2} \mathrm{SO}_{4}+10 \mathrm{NaNO}_{3}+4 \mathrm{NaCl} \rightarrow 2 \mathrm{CuCl}_{2}+\mathrm{Fe}_{2}\left(\mathrm{SO}_{4}\right)_{3}+10 \mathrm{NO}_{2}+4 \mathrm{~S} \\
+10 \mathrm{H}_{2} \mathrm{O}+7 \mathrm{Na}_{2} \mathrm{SO}_{4} .
\end{gathered}
$$

The results of applying $X$-ray diffraction to the pretreatment products are presented in Figure 7, which indicated the presence of quartz and chalcopyrite. Quartz continued to remain present because it is not reactive in acid solutions [37]. Chalcopyrite was most abundant, and it is evident that not all $\mathrm{CuFeS}_{2}$ reacted during the pretreatment, which concurs with what is shown in Figure 6. Additionally, the presence of natrojarosite $\left(\mathrm{NaFe}_{3}\left(\mathrm{SO}_{4}\right)_{2}(\mathrm{OH})_{6}\right)$ was evidenced, and it was formed from the association of $\mathrm{Na}$ and Fe (derived from $\mathrm{NaCl}$ and chalcopyrite).

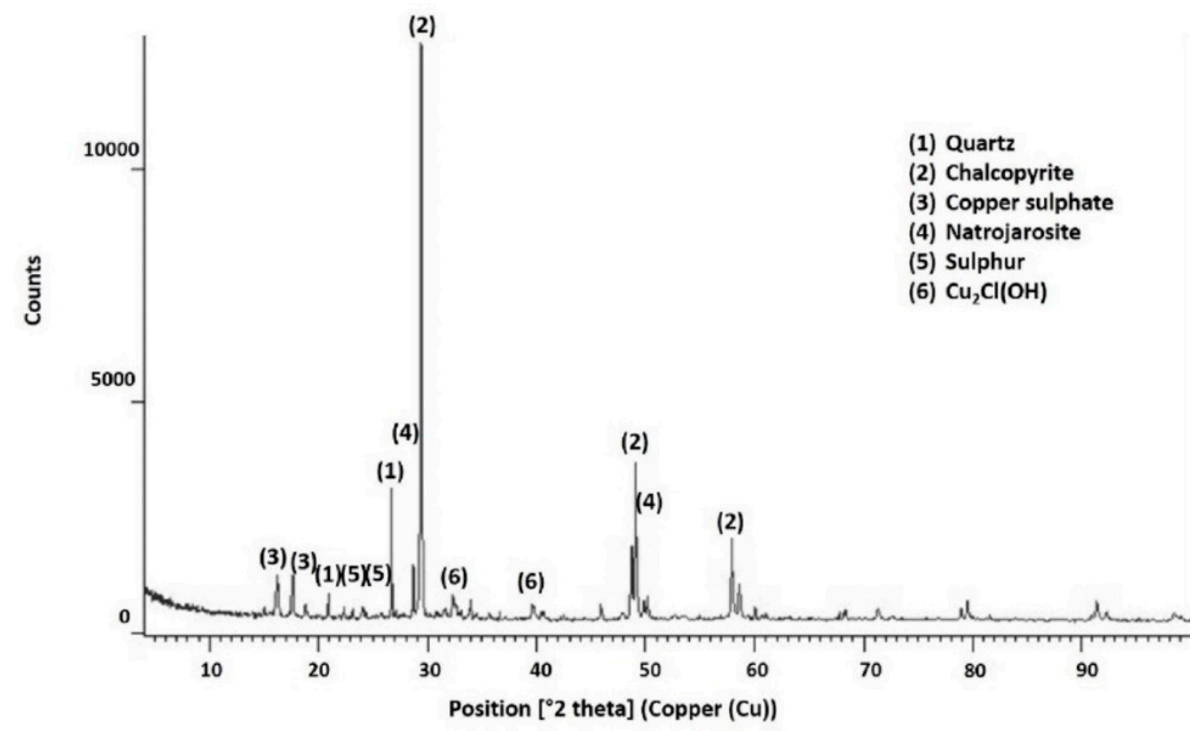

Figure 7. X-ray diffractogram for chalcopyrite agglomerated with $15 \mathrm{~kg} / \mathrm{t}$ of $\mathrm{H}_{2} \mathrm{SO}_{4}, 25 \mathrm{~kg} / \mathrm{t}$ of NaCl, and 15 days of curing time at room temperature.

Quartz, chalcopyrite, and natrojarosite are the most abundant species in the pretreatment product. Other products, such as $\mathrm{CuSO}_{4}, \mathrm{Cu}_{2} \mathrm{ClOH}$, and $\mathrm{S}^{0}$, were also identified. The presence of iron sulphate was reported as probable [18] (according to Reaction (4)). Likewise, the presence of elemental sulphur was proposed by [18,31]. These authors proposed the formation of a $\mathrm{CuCl}$ or $\mathrm{CuCl}_{2}$ complex, which differs from what was identified in this investigation.

The presence of $\mathrm{CuSO}_{4}, \mathrm{NaFe}_{3}\left(\mathrm{SO}_{4}\right)_{2}(\mathrm{OH})_{6}, \mathrm{~S}^{0}$, and $\mathrm{Cu}_{2} \mathrm{Cl}(\mathrm{OH})$ was confirmed by comparing the $\mathrm{X}$-ray diffractogram of the original chalcopyrite with the diffractogram of the pretreatment products. With the software X'pert HighScore Plus v.3.0e, the main angles of the peak characteristics of the different species were identified. The angle (in 2 theta) of $16.16^{\circ}$ was characteristic of $\mathrm{CuSO}_{4}$. Although $\mathrm{CuSO}_{4}$ was present in the initial sample as chalcanthite, the peak at $16.16^{\circ}$ denotes a greater presence of this species (or, at least, a similar species in the structure) (Figure 8). A copper extraction of $22.66 \%$ was obtained with the use of $15 \mathrm{~kg} / \mathrm{t}$ of $\mathrm{H}_{2} \mathrm{SO}_{4}, 25 \mathrm{~kg} / \mathrm{t}$ of NaCl , and 15 days of curing at room temperature. Considering that $9 \%$ of the copper extraction was associated with chalcanthite, more than $10 \%$ of the copper dissolved as a result of generating a new soluble species. 


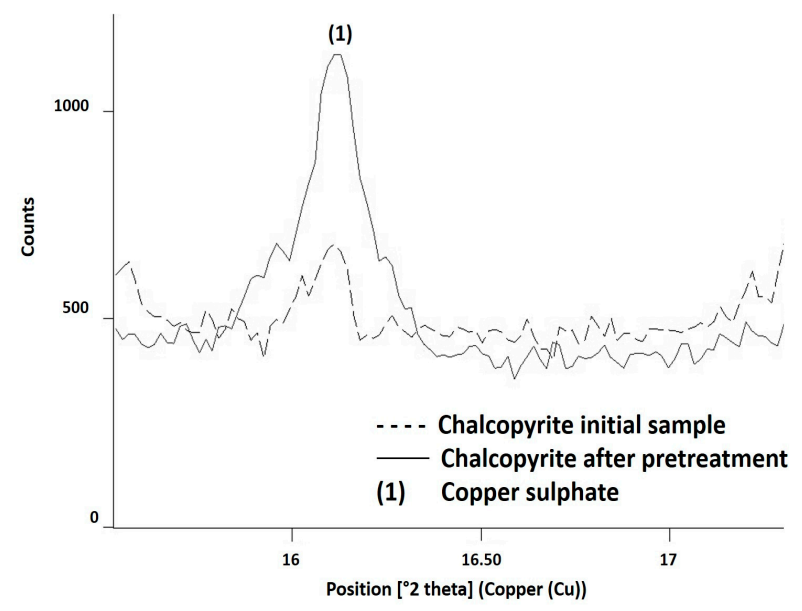

Figure 8. Identification of $\mathrm{CuSO}_{4}$ by X-ray diffraction analysis in chalcopyrite pretreated with $15 \mathrm{~kg} / \mathrm{t}$ of $\mathrm{H}_{2} \mathrm{SO}_{4}, 25 \mathrm{~kg} / \mathrm{t}$ of $\mathrm{NaCl}$, and 15 days of curing at room temperature.

Figure 9 shows the characteristic angles of natrojarosite, such as $28.65^{\circ}$ (Figure 9a) and $49.79^{\circ}$ (Figure $9 \mathrm{~b}$ ), with the peak at $28.65^{\circ}$ being the angle associated with an intensity of $95 \%$. According to [38], only four phases have been reported for the $\mathrm{Na}-\mathrm{Fe}-\mathrm{SO}_{4}-$ $\mathrm{OH}$ system: the natrojarosite $\mathrm{NaFe}_{3}\left(\mathrm{SO}_{4}\right)_{2}(\mathrm{OH})_{6}$, the jarosite $\mathrm{Na}_{0.84} \mathrm{Fe}_{2.86}\left(\mathrm{SO}_{4}\right)_{2}(\mathrm{OH})_{6}$, and two hydrated phases, the sideronatrite $\mathrm{Na}_{2} \mathrm{FeOH}\left(\mathrm{SO}_{4}\right)_{2} \cdot 3 \mathrm{H}_{2} \mathrm{O}$ and metasideronatrite $\mathrm{Na}_{2} \mathrm{FeOH}\left(\mathrm{SO}_{4}\right)_{2} \cdot \mathrm{H}_{2} \mathrm{O}$. These phases are minerals but could be prepared via precipitation or under hydrothermal conditions. Therefore, an iron hydrosulphate natrojarosite can form.

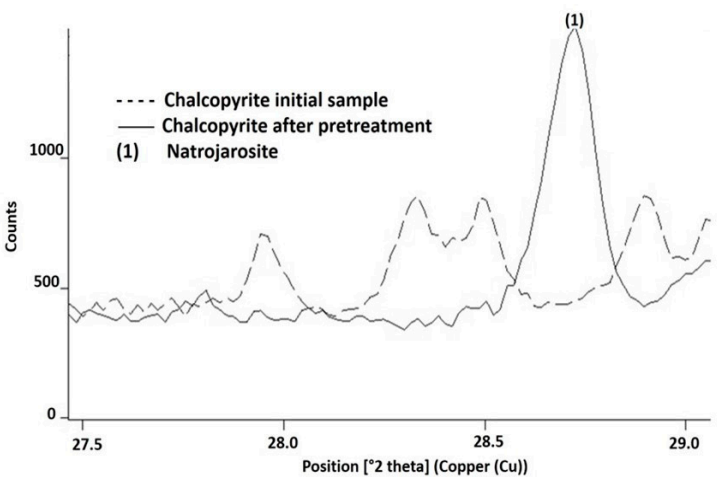

(a)

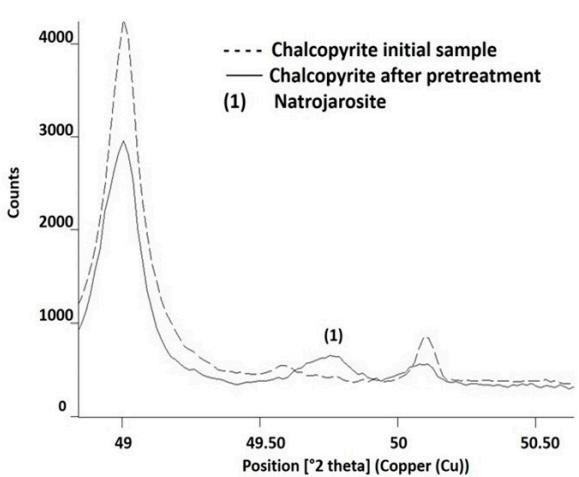

(b)

Figure 9. $\mathrm{NaFe}_{3}\left(\mathrm{SO}_{4}\right)_{2}(\mathrm{OH})_{6}$ identified by $\mathrm{X}$-ray diffraction, a product of the pretreatment of chalcopyrite mineral with $15 \mathrm{~kg} / \mathrm{t}$ of $\mathrm{H}_{2} \mathrm{SO}_{4}, 25 \mathrm{~kg} / \mathrm{t}$ of NaCl , and 15 days of curing at room temperature. In $(\mathbf{a}, \mathbf{b})$ the new presence of $\mathrm{NaFe}_{3}\left(\mathrm{SO}_{4}\right)_{2}(\mathrm{OH})_{6}$ was identified as (1), compared with the initial diffractogram of the sample.

The presence of $S^{0}$ was identified by XRD and was compared with the initial chalcopyrite sample. In Figure 10a, the presence of $S^{0}$ is demonstrated by the main angle of $23.07^{\circ}$, which represents an intensity of $100 \%$ in the case of $S^{0}$. According to [39], when no strong oxidative conditions are available to produce $\mathrm{SO}_{4}{ }^{2-}$, the predominant $\mathrm{S}$ product of chalcopyrite leaching is $\mathrm{S}^{0}$.

$\mathrm{Cu}_{2} \mathrm{Cl}(\mathrm{OH})$ was also identified by $X$-ray diffraction in the pretreated sample. Although the presence of this compound is demonstrated in Figure 11, the presence of other similar compounds, such as $\mathrm{Cu}_{2} \mathrm{ClO}_{3}$ or $\mathrm{Cu}_{2} \mathrm{Cl}(\mathrm{OH})_{3}$, cannot be ruled out. Under the studied conditions, the $\mathrm{Cu}_{2} \mathrm{Cl}(\mathrm{OH})$ had a better fit and recognition with the software used. The main peak was associated with the position $16.23^{\circ}$, which overlaps with the $\mathrm{CuSO}_{4}$ peak. However, other major peaks, such as $39.81^{\circ}$ and $32.42^{\circ}$, were identified and are shown in Figure $11 \mathrm{a}, \mathrm{b}$, respectively. 


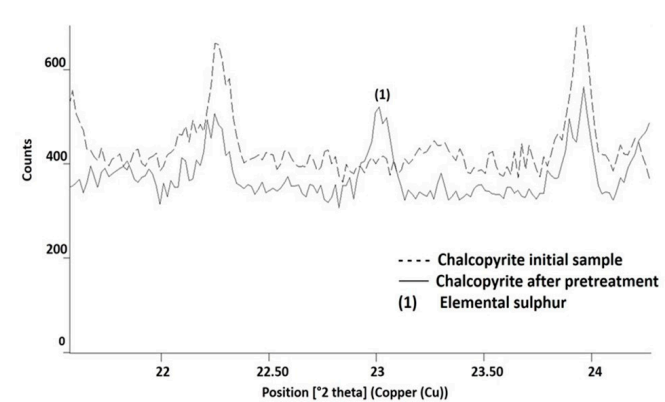

(a)

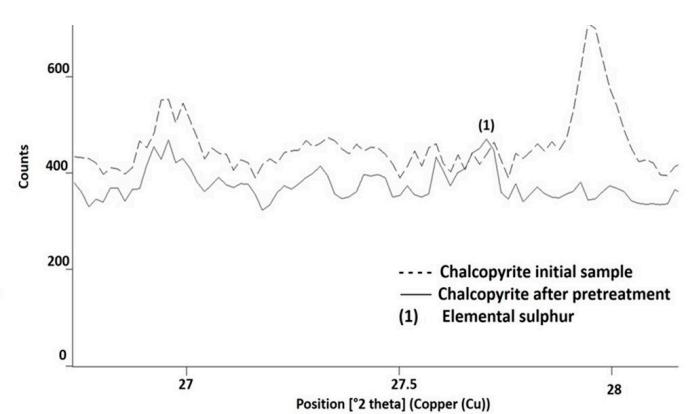

(b)

Figure 10. Elemental sulphur identified by $\mathrm{X}$-ray diffraction, a product of the pretreatment of chalcopyrite mineral with $15 \mathrm{~kg} / \mathrm{t}$ of $\mathrm{H}_{2} \mathrm{SO}_{4}, 25 \mathrm{~kg} / \mathrm{t}$ of NaCl , and 15 days of curing at room temperature. In $(\mathbf{a}, \mathbf{b})$ the new presence of elemental sulphur was identified as (1), compared with the initial diffractogram of the sample.

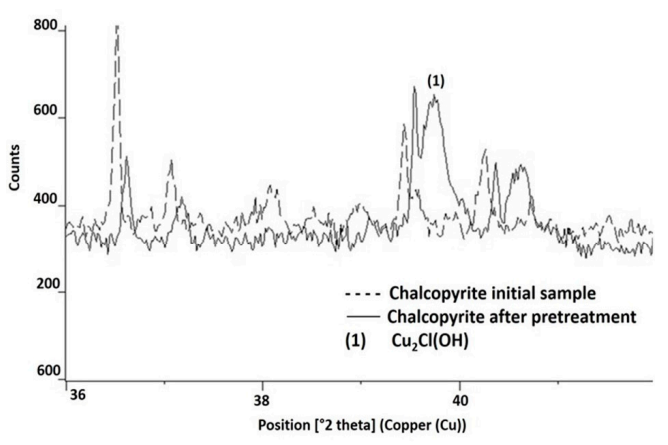

(a)

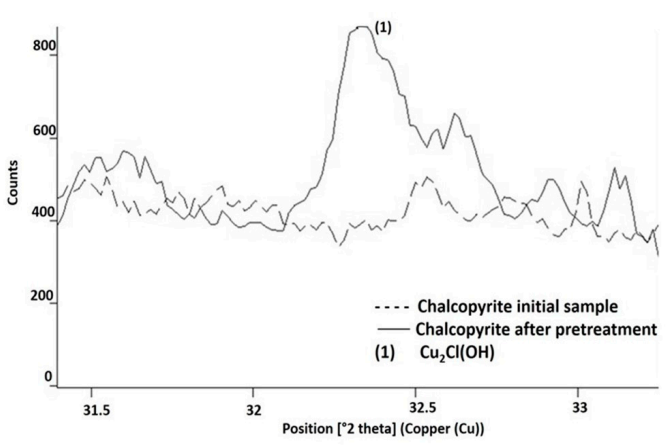

(b)

Figure 11. $\mathrm{Cu}_{2} \mathrm{Cl}(\mathrm{OH})$ identified by $\mathrm{X}$-ray diffraction, a product of the pretreatment of chalcopyrite mineral with $15 \mathrm{~kg} / \mathrm{t}$ of $\mathrm{H}_{2} \mathrm{SO}_{4}, 25 \mathrm{~kg} / \mathrm{t}$ of NaCl , and 15 days of curing at room temperature. In $(\mathbf{a}, \mathbf{b})$ the new presence of $\mathrm{Cu}_{2} \mathrm{Cl}(\mathrm{OH})$ was identified as (1), compared with the initial diffractogram of the sample.

The pretreated sample was also analysed by SEM. Figure 12 shows two images of unreacted or partially attacked chalcopyrite particles. Figure $12 \mathrm{~b}, \mathrm{~d}$ include the EDS analysis of zone 1 shown in Figure 12a,c. Through the semi-quantitative reporting of elements, copper and iron depletion in chalcopyrite were identified. Figure 12a shows an atomic Cu:Fe:S ratio of 1:1:2, which indicates original or unreacted chalcopyrite, while Figure $12 \mathrm{c}$ shows an atomic ratio $\mathrm{Cu}: \mathrm{Fe}: \mathrm{S}$ of 1:1:5, which denotes a lower atomic ratio against the chemical formula of chalcopyrite due to the dissolution of copper and iron. Cracks were evident on the surface of the particles and surrounding them.

Nicol et al. [40] reported that surface cracks and fissures appeared during electrolysis in tests in which a massive chalcopyrite electrode was cathodically leached at $20^{\circ} \mathrm{C}$ in $100 \mathrm{~g} / \mathrm{L}$ of $\mathrm{H}_{2} \mathrm{SO}_{4}$ at $-900 \mathrm{mV}$. The authors attributed the formation of cracks to the change in molar volume as chalcopyrite transformed into chalcocite and a copper-deficient sulphide, CuS.

Figure 13a shows the presence of chalcopyrite (1), copper sulphate (2), and natrojarosite (3). Figure $13 \mathrm{~b}$ shows an enlargement of the area where the natrojarosite was found. The EDS analysis associated with copper sulphate is reported in Figure 13c. Si and Al were identified, which would be associated with a silicate, such as albite $\left(\mathrm{NaAlSi}_{3} \mathrm{O}_{8}\right)$, and the sodium was overlapped by copper with a low presence. The semiquantitative analysis indicated that, in terms of the atomic \%, the Cu:S:O ratio was 1:1:5 to make up the formula for $\mathrm{CuSO}_{4}$. Figure 13d shows the EDS analysis of the detected natrojarosite (3). The semiquantitative analysis indicated an Na:Fe:S:O atomic ratio of 0.8:2.3:3:7.6 ratio close to the natrojarosite $\mathrm{NaFe}_{2.3}\left(\mathrm{SO}_{4}\right)_{2}(\mathrm{OH})_{6}$ formula of 1:2.3:2:14, as observed in other natural and synthetic jarosites. 

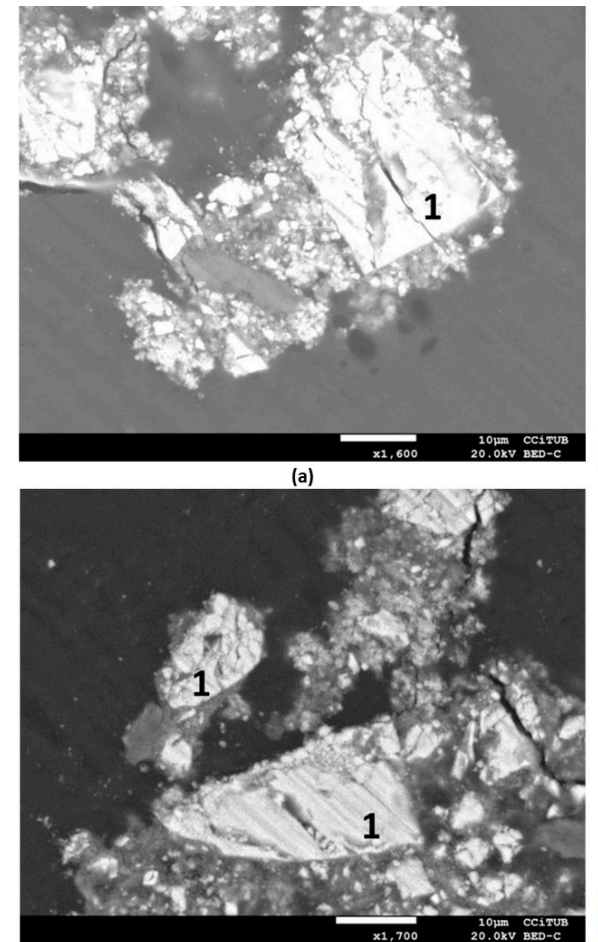

(c)

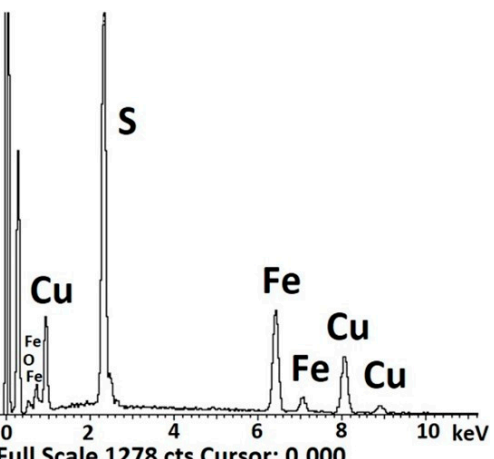

(b)

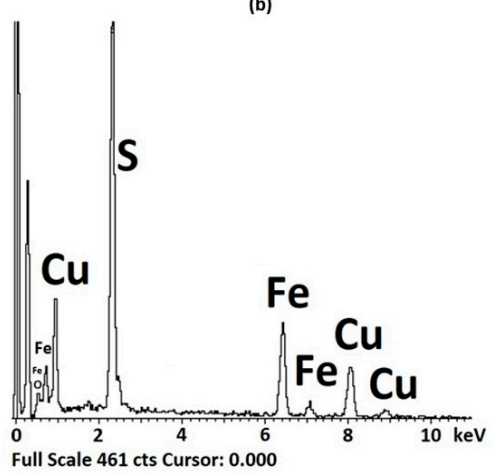

(d)

Figure 12. SEM images (a,c) and EDS analysis (b,d) of chalcopyrite in (1) after treatment with $15 \mathrm{~kg} / \mathrm{t}$ of $\mathrm{H}_{2} \mathrm{SO}_{4}, 25 \mathrm{~kg} / \mathrm{t} \mathrm{NaCl}$, and 15 days of curing time at room temperature. In (a) at a magnification of $\times 1.600$ and $(\mathbf{c})$ at $\times 1.700$.

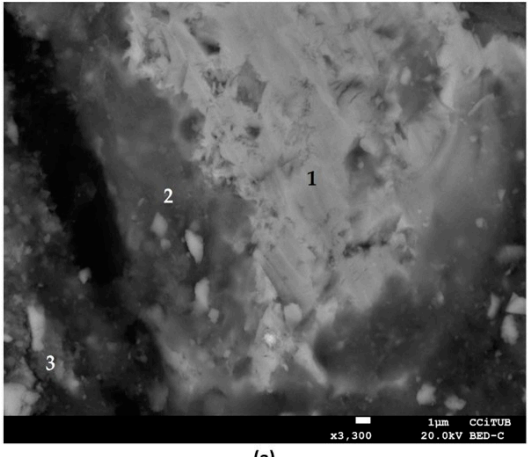

(a)

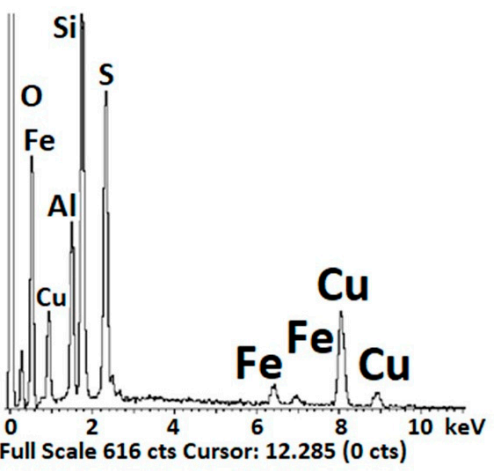

(c)

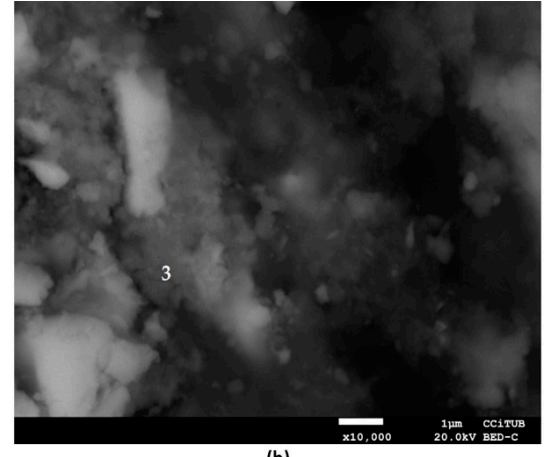

(b)

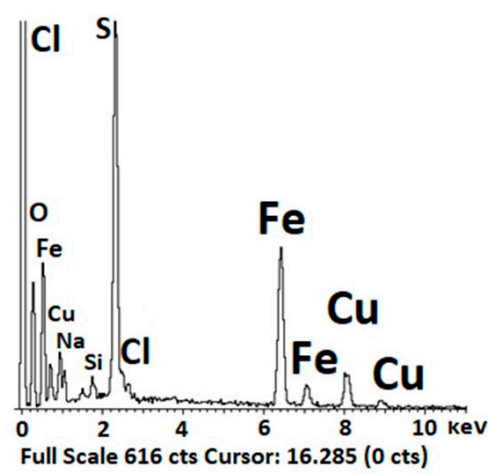

(d)

Figure 13. SEM images (a,b) and EDS analysis of chalcopyrite (1) and reaction products, such as $\mathrm{CuSO}_{4}$ (2) (EDS in (c)) and $\mathrm{NaFe}_{3}\left(\mathrm{SO}_{4}\right)_{2}(\mathrm{OH})_{6}$ (3) (EDS in (d)), products of the pretreatment of chalcopyrite mineral with $15 \mathrm{~kg} / \mathrm{t}$ of $\mathrm{H}_{2} \mathrm{SO}_{4}, 25 \mathrm{~kg} / \mathrm{t}$ of NaCl , and 15 days of curing time at room temperature. In (a) at a magnification of $\times 3.300$ and $(\mathbf{b})$ at $\times 10.000$. 
Figure $14 \mathrm{a}$ identifies a compound associated with $\mathrm{Cu}_{2} \mathrm{Cl}(\mathrm{OH})$. Figure $14 \mathrm{~b}$ presents the EDS analysis associated with Figure 14a. The atomic ratio of $\mathrm{Cu}: \mathrm{Cl}: \mathrm{O}$ of 1.9:1:3.3 is sufficient for the formation of the proposed compound. However, because $\mathrm{H}$ was not reported by the EDS analysis, the formation of $\mathrm{Cu}_{2} \mathrm{ClO}$ should not be discarded.

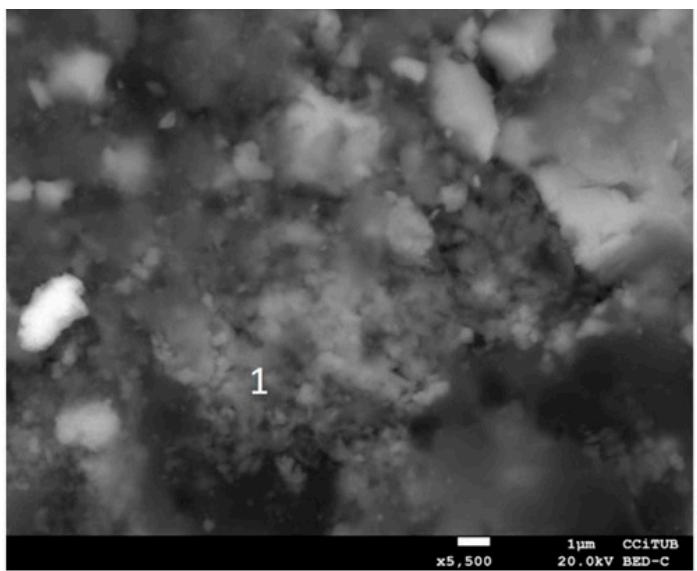

(a)

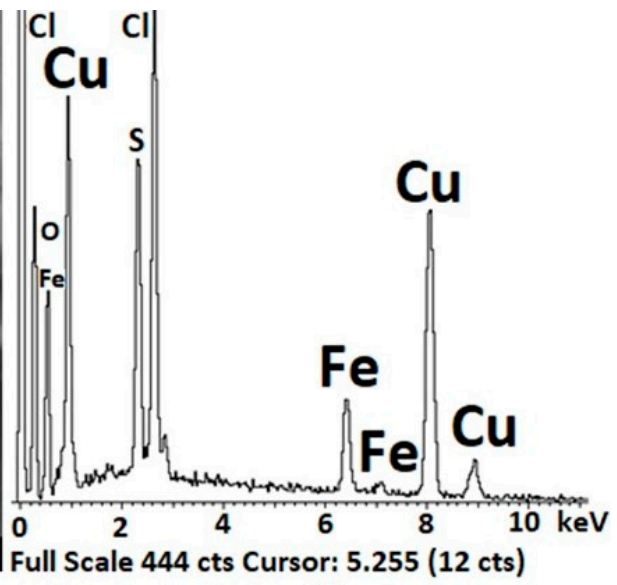

(b)

Figure 14. SEM image (a) and EDS analysis (b) of zone 1. The EDS confirms the formation of $\mathrm{Cu}_{2} \mathrm{Cl}(\mathrm{OH})(1)$ in the products of the pretreatment of chalcopyrite mineral with $15 \mathrm{~kg} / \mathrm{t}$ of $\mathrm{H}_{2} \mathrm{SO}_{4}$, $25 \mathrm{~kg} / \mathrm{t} \mathrm{NaCl}$, and 15 days of curing at room temperature. In (a) at a magnification of $\times 5.500$.

Considering all the characterisation techniques applied on the chalcopyrite pretreatment products, the following reaction is proposed under the conditions used in this study. The treatment of a sample of natural chalcopyrite with concentrations of $15 \mathrm{~kg} / \mathrm{t}$ of $\mathrm{H}_{2} \mathrm{SO}_{4}$, $25 \mathrm{~kg} / \mathrm{t}$ of $\mathrm{NaCl}$, and 15 days of curing is governed by Reaction (5).

$$
3 \mathrm{CuFeS}_{2}+3.5 \mathrm{H}_{2} \mathrm{SO}_{4}+\mathrm{NaCl}+2.5 \mathrm{O}_{2} \rightarrow \mathrm{CuSO}_{4}+\mathrm{NaFe}_{3}\left(\mathrm{SO}_{4}\right)_{2}(\mathrm{OH})_{6}+6.5 \mathrm{~S}+\mathrm{Cu}_{2} \mathrm{Cl}(\mathrm{OH})
$$

\subsection{Leaching Yields}

To evaluate the effects of the curing time, chalcopyrite samples with pretreatment (agglomerated and cured with $15 \mathrm{~kg} / \mathrm{t}$ of $\mathrm{H}_{2} \mathrm{SO}_{4}$ and $25 \mathrm{~kg} / \mathrm{t}$ of NaCl for a period of 15 days) and without pretreatment were leached at $25,50,70$, and $90{ }^{\circ} \mathrm{C}$.

Figure 15 a shows the results of the leaching tests without pretreatment. A tendency was observed that the copper extraction benefitted from increases in the temperature. At temperatures above $25{ }^{\circ} \mathrm{C}$ (ambient), a less protective and more porous passivating layer was formed, which allowed the dissolution of chalcopyrite [41]. Tests without pretreatment behaved almost identically in the first two hours of leaching, reaching a copper extraction of about $16 \%$, considering that $9 \%$ of the copper was initially soluble (copper sulphate dissolution). The copper extraction curves changed after four hours owing to the effect of temperature. The tests at 90 and $70{ }^{\circ} \mathrm{C}$ yielded copper extractions of $90 \%$ and $87 \%$, respectively, while the tests at 50 and $25{ }^{\circ} \mathrm{C}$ yielded copper extractions of $71 \%$ and $30 \%$, respectively.

The test at $25^{\circ} \mathrm{C}$ copper extraction reached a plateau at $24 \mathrm{~h}$ of leaching (by passivation), while the test at $50^{\circ} \mathrm{C}$ achieved a plateau at $36 \mathrm{~h}$. The test at $70^{\circ} \mathrm{C}$ did not clearly demonstrate passivation. The test at $90^{\circ} \mathrm{C}$ had the highest copper extraction, although not as much higher than the test at $70^{\circ} \mathrm{C}$. A similar trend in the results was shown in [42] in a chalcopyrite leaching test between 85 and $95^{\circ} \mathrm{C}$. For tests performed at $25^{\circ} \mathrm{C}$, there was a limited dissolution of copper, which is consistent with the view that the dissolution of chalcopyrite requires temperatures between 35 and $95{ }^{\circ} \mathrm{C}[14,41]$. 


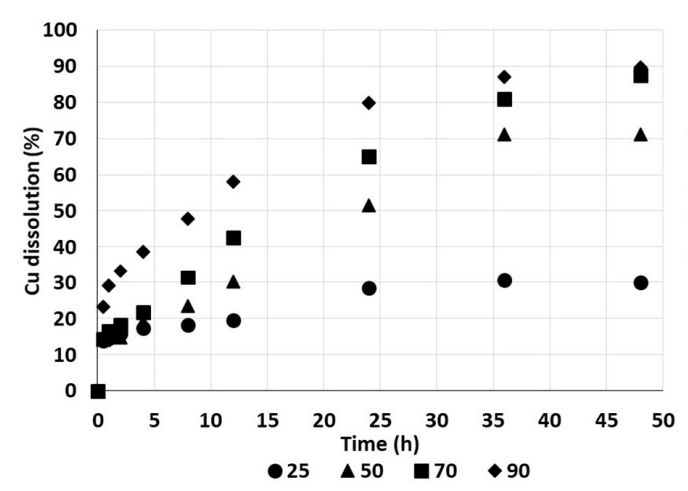

(a)

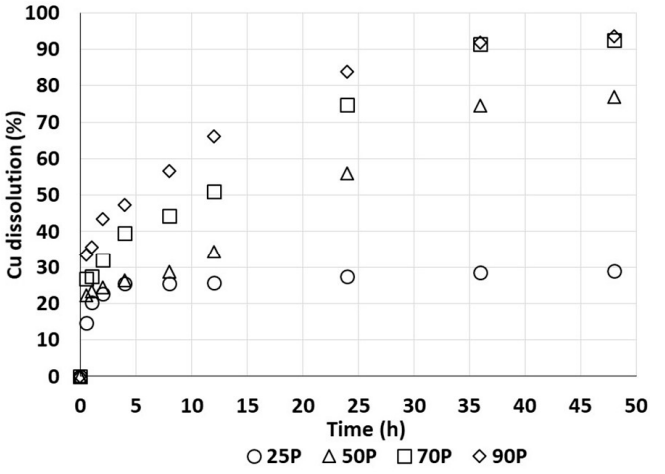

(b)

Figure 15. The dissolution of copper from chalcopyrite without pretreatment (a) in $0.2 \mathrm{M}$ of $\mathrm{H}_{2} \mathrm{SO}_{4}$ and $50 \mathrm{~g} / \mathrm{L}$ of $\mathrm{Cl}^{-}$ions from $\mathrm{NaCl}$ in deionised water at $25^{\circ} \mathrm{C}(\bullet 25), 50{ }^{\circ} \mathrm{C}(\boldsymbol{\Delta} 50), 70^{\circ} \mathrm{C}(\boldsymbol{\square} 70)$, and $90{ }^{\circ} \mathrm{C}(\diamond 90)$ and with pretreatment $(\mathbf{b})$ at $25^{\circ} \mathrm{C}(\bigcirc 25 \mathrm{P}), 50{ }^{\circ} \mathrm{C}(\triangle 50 \mathrm{P}), 70{ }^{\circ} \mathrm{C}(\square 70 \mathrm{P})$, and $90{ }^{\circ} \mathrm{C}(\diamond 90 \mathrm{P})$.

As chalcanthite is present in the system, it is possible to rapidly obtain a fraction of dissolved copper. A 9\% copper extraction is associated with the presence of chalcanthite, which represents $0.5 \mathrm{~g} / \mathrm{L}$ of $\mathrm{Cu}^{2+}$ in the initial stage of leaching. Although this work did not include tests to evaluate the effect of cupric, other authors [43,44] have demonstrated the benefit of $\mathrm{Cu}^{2+}$ in the initial stage of chalcopyrite dissolution. According to [45], the presence of a small amount of cupric is important in achieving an acceptable chalcopyrite leaching; however, concentrations above $0.1 \mathrm{~g} / \mathrm{L}$ did not increase the dissolution.

Figure $15 \mathrm{~b}$ shows the results of the leaching tests with pretreatment. Tests with pretreatment are indicated by $(\mathrm{P})$. As can be seen, the tests at $90,70,50$, and $25^{\circ} \mathrm{C}$ yielded copper extractions of $94 \%, 92 \%, 77 \%$, and $29 \%$, respectively. The copper extraction yields in the tests without pretreatment also increased with higher temperatures. However, the extraction yields of the pretreated tests at 70 and $50{ }^{\circ} \mathrm{C}$ were almost $5 \%$ higher than those of the untreated tests at the same temperature, while the test at $90^{\circ} \mathrm{C}$ achieved an almost complete copper dissolution. A passivation curve can be seen at $24 \mathrm{~h}$ of leaching in the test at $25^{\circ} \mathrm{C}$. However, the dissolution kinetics, which benefitted from the soluble phases in the pretreatment, were identical to the dissolution kinetics in the first four hours of leaching in the test at $50{ }^{\circ} \mathrm{C}[46]$.

Comparing the tests with and without pretreatment, the curing time increased the copper extraction by $6 \%$ on average, compared to the rates in the tests without pretreatment (at 50 and $70^{\circ} \mathrm{C}$ ). The curing time benefitted copper extraction over time, favouring the oxidation of sulphide minerals [47]. Stable copper extraction curves were reached earlier in the tests with curing than in those without curing, which was due to the sulphation generated with pretreatment, which mainly formed copper sulphate.

Tests with acid curing accelerated the dissolution kinetics in the first $4 \mathrm{~h}$ of treatment. The results concur with those proposed by [32], who found that curing time increased the copper extraction by about $5 \%$ in column leaching tests using a chalcopyrite mineral. The same copper extraction was obtained in much less time at $90^{\circ} \mathrm{C}$ compared with at $70{ }^{\circ} \mathrm{C}$, or at $70{ }^{\circ} \mathrm{C}$ compared with at $50^{\circ} \mathrm{C}$. For comparative purposes, and during leaching at $70^{\circ} \mathrm{C}$, copper extractions of $75 \%$ in $24 \mathrm{~h}$ with pretreatment and in $32 \mathrm{~h}$ without pretreatment were obtained. During leaching at $90{ }^{\circ} \mathrm{C}$, copper extractions of $84 \%$ in $24 \mathrm{~h}$ with pretreatment and in $32 \mathrm{~h}$ without pretreatment were obtained. Thus, the curing treatment significantly reduced the leaching time. Consequently, curing is considered beneficial to save agitated reactor and energy inputs. Curing processes only require time for the reactivity of the mineral and the solution (reagents). Table 3 shows a summary of the copper yields obtained via leaching test. 
Table 3. Summary of the copper yields obtained via leaching test with and without pretreatment.

\begin{tabular}{ccc}
\hline Test & Pretreatment & \% Copper Extraction \\
\hline$\bullet 25$ & No & 28.5 \\
$\bigcirc 25 \mathrm{P}$ & Yes & 27.5 \\
$\Delta 50$ & No & 51.5 \\
$\triangle 50 \mathrm{P}$ & Yes & 56.0 \\
$\square 70$ & No & 65.0 \\
$\square 70 \mathrm{P}$ & Yes & 74.8 \\
$\diamond 90$ & No & 79.8 \\
$\diamond 90 \mathrm{P}$ & Yes & 83.9 \\
\hline
\end{tabular}

Characteristics of Leach Residues

Leach residues from all the tests were characterised using XRD and SEM. Table 4 shows the main species identified in the corresponding diffractograms. Figures 16 and 17 show the information from the diffractograms of the residue, respectively, from the tests with the lowest copper extraction (at $25^{\circ} \mathrm{C}$ without pretreatment) and the highest copper extraction (at $90^{\circ} \mathrm{C}$ with pretreatment).

Table 4. Summary of the species identified using X-ray diffraction analysis. Tests with pretreatment are indicated by $(\mathrm{P})$.

\begin{tabular}{|c|c|c|}
\hline Test & More Abundant Species & Less Abundant Species \\
\hline $25^{\circ} \mathrm{C}(\mathrm{P})$ & $\mathrm{CuFeS}_{2}, \mathrm{SiO}_{2}, \mathrm{~S}$, and $\mathrm{FeS}_{2}$ & $\mathrm{CuS}, \mathrm{NaFe}_{3}\left(\mathrm{SO}_{4}\right)_{2}(\mathrm{OH})_{6}$, and $\mathrm{CuS}_{2}$ \\
\hline $25^{\circ} \mathrm{C}$ & $\mathrm{CuFeS}_{2}, \mathrm{SiO}_{2}, \mathrm{~S}$, and $\mathrm{FeS}_{2}$ & $\mathrm{CuS}, \mathrm{NaFe}_{3}\left(\mathrm{SO}_{4}\right)_{2}(\mathrm{OH})_{6}$, and $\mathrm{CuS}_{2}$ \\
\hline $50{ }^{\circ} \mathrm{C}(\mathrm{P})$ & $\mathrm{CuFeS}_{2}, \mathrm{SiO}_{2}, \mathrm{~S}, \mathrm{CuS}$, and $\mathrm{FeS}_{2}$ & $\mathrm{NaFe}_{3}\left(\mathrm{SO}_{4}\right)_{2}(\mathrm{OH})_{6}$ and $\mathrm{CuS}_{2}$ \\
\hline $50{ }^{\circ} \mathrm{C}$ & $\mathrm{CuFeS}_{2}, \mathrm{SiO}_{2}, \mathrm{~S}, \mathrm{CuS}$, and $\mathrm{FeS}_{2}$ & $\mathrm{NaFe}_{3}\left(\mathrm{SO}_{4}\right)_{2}(\mathrm{OH})_{6}$ and $\mathrm{CuS}_{2}$ \\
\hline $70{ }^{\circ} \mathrm{C}(\mathrm{P})$ & $\mathrm{SiO}_{2}, \mathrm{~S}$, and $\mathrm{FeS}_{2}$ & $\mathrm{CuFeS}_{2}, \mathrm{CuS}, \mathrm{NaFe}_{3}\left(\mathrm{SO}_{4}\right)_{2}(\mathrm{OH})_{6}$, and $\mathrm{CuS}_{2}$ \\
\hline $70{ }^{\circ} \mathrm{C}$ & $\mathrm{SiO}_{2}, \mathrm{~S}$, and $\mathrm{FeS}_{2}$ & $\mathrm{CuFeS}_{2}, \mathrm{CuS}, \mathrm{NaFe}_{3}\left(\mathrm{SO}_{4}\right)_{2}(\mathrm{OH})_{6}$, and $\mathrm{CuS}_{2}$ \\
\hline $90^{\circ} \mathrm{C}(\mathrm{P})$ & $\mathrm{SiO}_{2}$ and $\mathrm{S}$ & $\mathrm{CuFeS}_{2}, \mathrm{FeS}_{2}, \mathrm{CuS}$, and $\mathrm{NaFe}_{3}\left(\mathrm{SO}_{4}\right)_{2}(\mathrm{OH})_{6}$ \\
\hline $90{ }^{\circ} \mathrm{C}$ & $\mathrm{SiO}_{2}$ and $\mathrm{S}$ & $\mathrm{CuFeS}_{2}, \mathrm{FeS}_{2}, \mathrm{CuS}$, and $\mathrm{NaFe}_{3}\left(\mathrm{SO}_{4}\right)_{2}(\mathrm{OH})_{6}$ \\
\hline
\end{tabular}

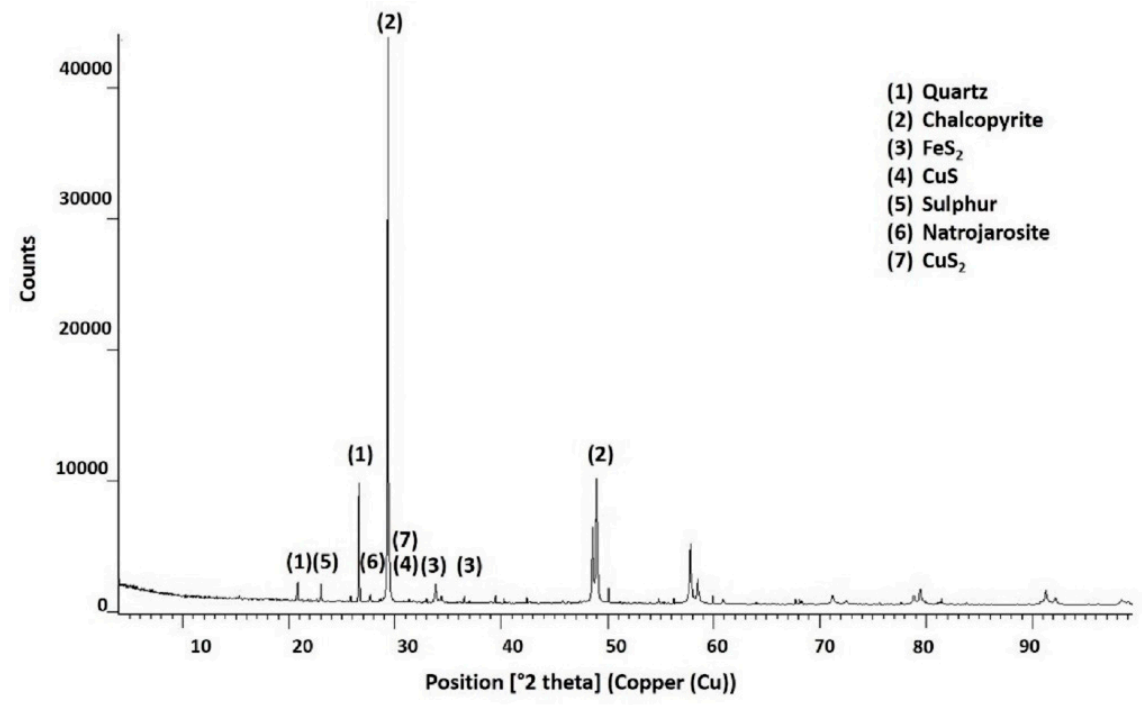

Figure 16. Species identified by $\mathrm{X}$-ray diffraction in residues after chalcopyrite leaching at $25^{\circ} \mathrm{C}$ without pretreatment. 


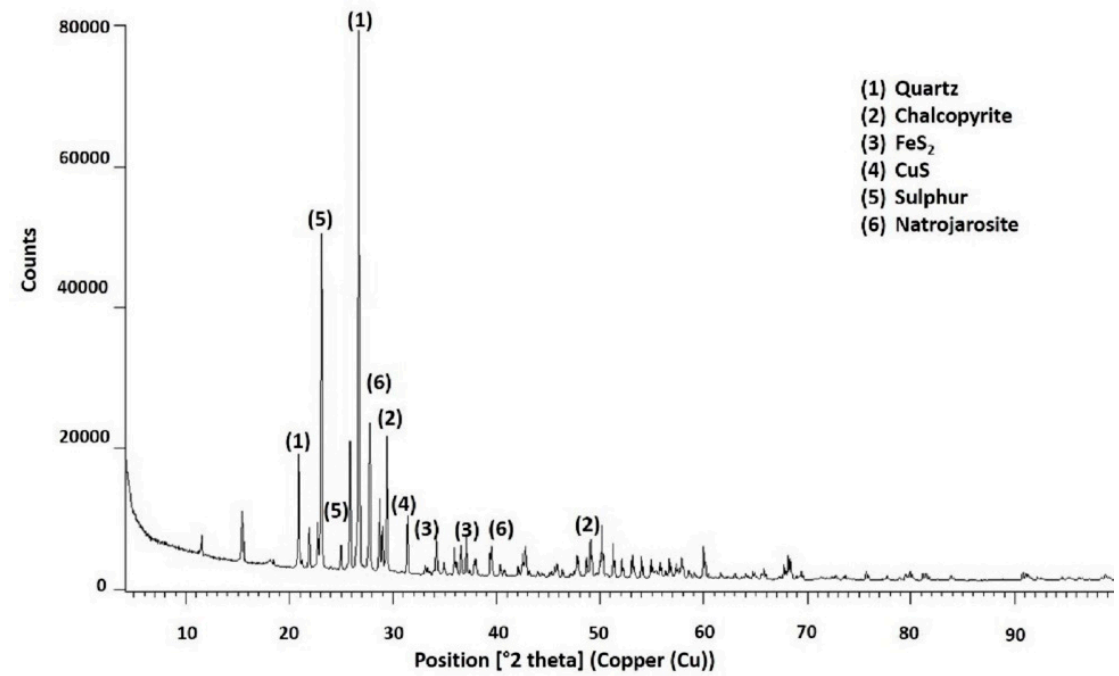

Figure 17. Species identified by $\mathrm{X}$-ray diffraction in residues after chalcopyrite leaching at $90{ }^{\circ} \mathrm{C}$ after pretreatment with $15 \mathrm{~kg} / \mathrm{t}$ of $\mathrm{H}_{2} \mathrm{SO}_{4}$ and $25 \mathrm{~kg} / \mathrm{t}$ of $\mathrm{NaCl}$ and 15 days of curing.

The X-ray diffractions of residues obtained at $25^{\circ} \mathrm{C}$ indicated that they were composed mainly of chalcopyrite and quartz. Small amounts of $\mathrm{CuS}_{2}$ polysulphide and natrojarosite species were observed to inhibit chalcopyrite leaching under these experimental conditions $[10,48,49]$. Elemental sulphur was also detected by XRD.

The same tendency was observed in the tests with and without pretreatment at $50{ }^{\circ} \mathrm{C}$, although with a notable increase in elemental sulphur. In tests at $70^{\circ} \mathrm{C}$, the dominance of elemental sulphur and quartz was observed, while minor quantities of chalcopyrite and natrojarosite were also detected. At this temperature, $\mathrm{CuS}_{2}$ in small amounts was also observed. The main angle of $\mathrm{CuS}_{2}$ overlapped with that of sulphur $\left(31.4^{\circ}\right)$; other angles of these species were also detected.

Although it is unclear if $\mathrm{CuS}_{2}$ was present, this cannot be ruled out. Clearly, the increased presence of $S^{0}$ was due to the product released by the leached chalcopyrite, which benefited from temperature and pretreatment. Leaching tests at 50 and $70{ }^{\circ} \mathrm{C}$ also showed the presence of covellite, which may be a product of the dissolution of chalcopyrite. Tests carried out at $90^{\circ} \mathrm{C}$ showed the presence of an abundant amount of elemental sulphur and quartz. The presence of unreacted chalcopyrite and natrojarosite was also evident.

Temperature [50] is a key factor in the formation of jarosite $\left(\mathrm{MFe}_{3}\left(\mathrm{SO}_{4}\right)(\mathrm{OH})_{6}\right.$ where $\mathrm{M}=\mathrm{Na}, \mathrm{K}, \mathrm{Rb}$, or $\mathrm{NH}_{4}$ ). Iron precipitation increases significantly with higher temperatures, especially in the range of 70 to $110{ }^{\circ} \mathrm{C}$. According to [42], the formation of natrojarosite occurred at $\mathrm{pH}$ values close to 0.9 in tests at $95^{\circ} \mathrm{C}$. Natrojarosite can form in chloride media, in accordance with Reaction (6). A problem associated with the precipitation of natrojarosite is that decreasing the acid concentration also slightly decreases the rate of copper extraction due to chalcopyrite passivation [49,51,52].

$$
3 \mathrm{Fe}^{3+}+2 \mathrm{SO}_{4}{ }^{2-}+6 \mathrm{H}_{2} \mathrm{O}+\mathrm{Na}^{+} \rightarrow \mathrm{NaFe}_{3}\left(\mathrm{SO}_{4}\right)_{2}(\mathrm{OH})_{6}+6 \mathrm{H}^{+}
$$

In summary, elemental sulphur and natrojarosite appeared in all leaching experiments by XRD analysis, and their content was more abundant at higher temperatures. Copper polysulphide was identified by XRD analysis in leach residues at 25,50 , and $70^{\circ} \mathrm{C}$.

Figure 18 shows an SEM image of the leaching residue at $70{ }^{\circ} \mathrm{C}$ with pretreatment. Unreacted chalcopyrite particles (1) were observed appearing as leaching products on the surface. Figure 19 shows a sequence of SEM images and mapping analysis for four chalcopyrite particles remaining in the residue from leaching at $70{ }^{\circ} \mathrm{C}$ with pretreatment (Figure 18). The elements analysed were $\mathrm{Cu}, \mathrm{Fe}$, and S. Figure 19b,d show the presence, respectively, of $\mathrm{Cu}$ and $\mathrm{S}$ around the chalcopyrite particles. 


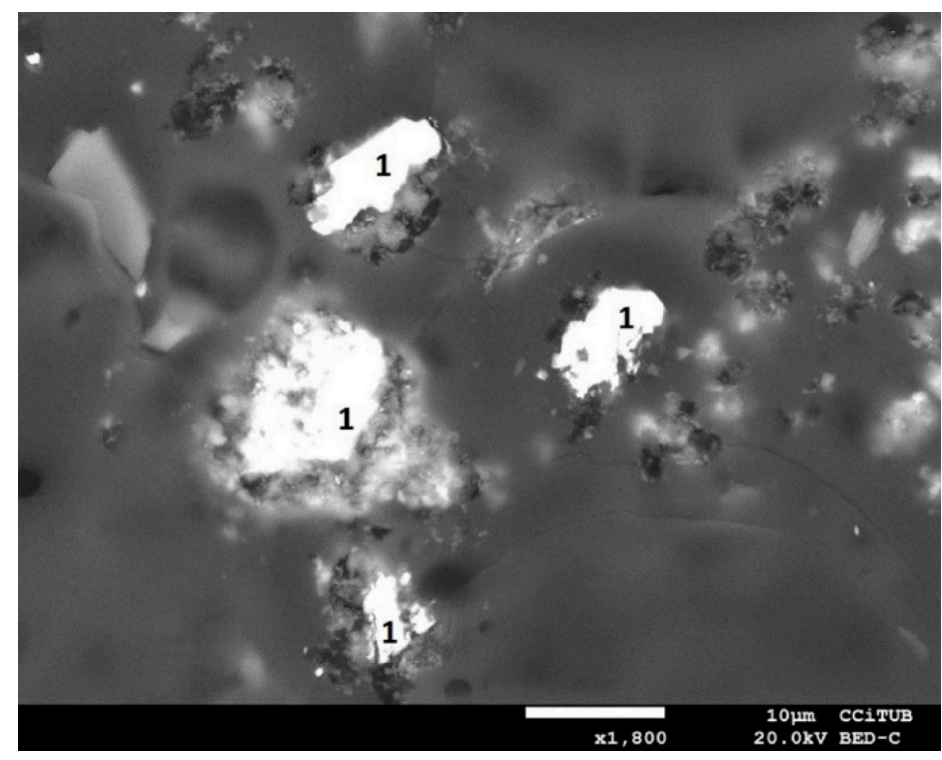

Figure 18. SEM image of the leaching residue from the test at $70{ }^{\circ} \mathrm{C}$ with pretreatment. $\mathrm{CuFeS}_{2}$ identified with (1).

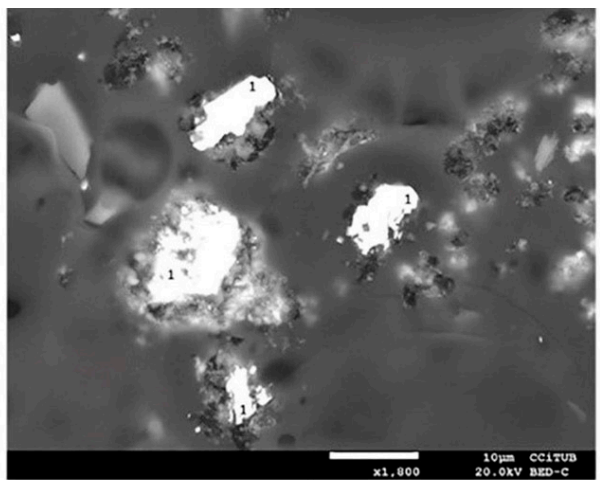

(a)

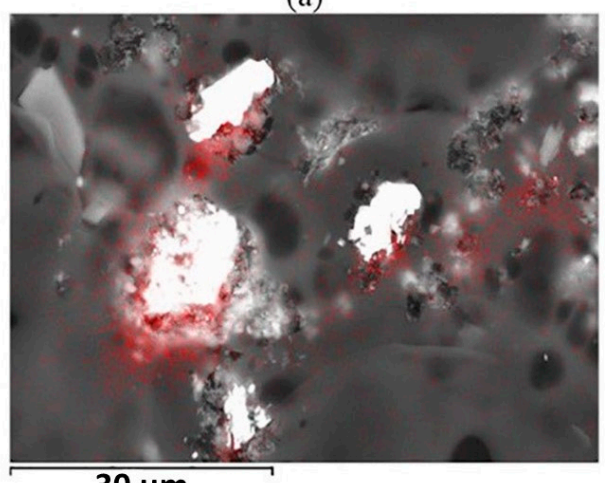

(c)

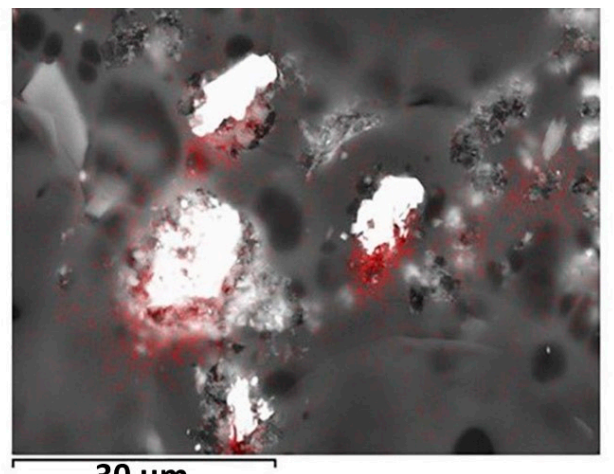

(b)

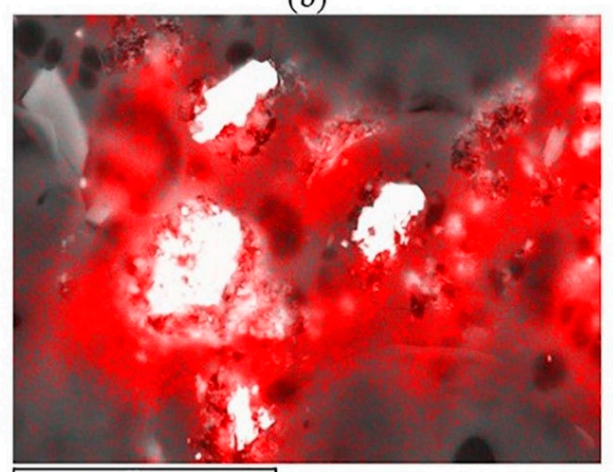

(d)

Figure 19. SEM mapping analysis of the leaching residue performed at $70{ }^{\circ} \mathrm{C}$ with pretreatment. (a) Chalcopyrite particles (1). Elements of interest are shown in red: (b) Cu, (c) Fe, and (d) S [46].

The presence of copper and sulphur around the chalcopyrite were associated with $\mathrm{CuS}_{2}$ or a similar polysulphide. The passivation associated with polysulphides $\left(\mathrm{CuS}_{2}\right)$ is explained in terms of the selective dissolution of iron as in a conventional process to form a thick layer of copper polysulphide over time. Additionally, in all the tests at $70{ }^{\circ} \mathrm{C}$, the oxidation-reduction potential was measured in the range of $600-700 \mathrm{mV}$ (SHE). This range is considered appropriate to form $\mathrm{CuS}_{2}$ or other polysulphides [48]. 
While Figure 19 shows an abundance of elemental sulphur, the authors, including [49] with chalcopyrite leaching tests at $68{ }^{\circ} \mathrm{C}$, proposed that the elemental sulphur formed during chalcopyrite dissolution is porous and does not contribute to the passivation of the surface of chalcopyrite. The authors proposed that species, such as jarosite, are responsible for passivating chalcopyrite. Based on tests at $90{ }^{\circ} \mathrm{C}$ using $\mathrm{FeCl}_{3}$ and $\mathrm{HCl}$, other researchers [53] indicated that the elemental sulphur layer formed on the chalcopyrite surface after leaching in a ferric chloride solution is porous and is not a barrier to further leaching. The results obtained in the present study confirmed that the porosity of the products layer increased with temperature.

\section{Conclusions}

The pretreatment of chalcopyrite with a sodium chloride-sulphuric acid media system $\left(15 \mathrm{~kg} / \mathrm{t}\right.$ of $\mathrm{H}_{2} \mathrm{SO}_{4}$ and $25 \mathrm{~kg} / \mathrm{t}$ of $\mathrm{NaCl}$ with 15 days of curing) resulted in a copper extraction of $22.66 \%$ prior to leaching. The presence of copper sulphate, natrojarosite, elemental sulphur, and copper hydroxychloride was detected by characterisation of the curing products. The stoichiometry proposed for this process is Reaction (5): $3 \mathrm{CuFeS}_{2}+3.5 \mathrm{H}_{2} \mathrm{SO}_{4}+\mathrm{NaCl}+2.5 \mathrm{O}_{2} \cdot \rightarrow \mathrm{CuSO}_{4}+\mathrm{NaFe}_{3}\left(\mathrm{SO}_{4}\right)_{2}(\mathrm{OH})_{6}+6.5 \mathrm{~S}+\mathrm{Cu}_{2} \mathrm{Cl}(\mathrm{OH})$.

Curing time benefits the kinetics of leaching copper from pretreated chalcopyrite. In synergy with temperatures of 50 and $90{ }^{\circ} \mathrm{C}$, curing resulted in a copper extraction that was $6 \%$ higher than the extraction obtained without any curing time. A copper extraction of $94 \%$ was obtained at $90{ }^{\circ} \mathrm{C}$ with a pretreatment of $15 \mathrm{~kg} / \mathrm{t}$ of $\mathrm{H}_{2} \mathrm{SO}_{4}$ and $25 \mathrm{~kg} / \mathrm{t}$ of $\mathrm{NaCl}$ with 15 days of curing time, while an extraction of $90 \%$ was obtained at the same temperature but without pretreatment.

Copper extractions of $75 \%$ were obtained in $24 \mathrm{~h}$ at $70{ }^{\circ} \mathrm{C}$ with pretreatment and in $32 \mathrm{~h}$ at the same temperature without pretreatment, while at $90^{\circ} \mathrm{C}$, extractions of $84 \%$ were obtained in $24 \mathrm{~h}$ with pretreatment and in $32 \mathrm{~h}$ without pretreatment. Thus, the curing applied significantly reduced the leaching time.

The test at $25{ }^{\circ} \mathrm{C}$ led to a copper extraction close to $30 \%$, with or without curing pretreatment, which confirms that the surface of chalcopyrite is passivated at this temperature by the formation of a compact layer of sulphur, likely with the formation of jarosite and copper polysulphides.

The surface of elemental sulphur formed at $70{ }^{\circ} \mathrm{C}$ appeared to have a more porous and less rigid surface than the surfaces of the leaching products at $25^{\circ} \mathrm{C}$. A more porous film of sulphur bordering the surface of the chalcopyrite allowed contact between the leaching solution and the mineral.

Abundant elemental sulphur and natrojarosite were identified in all the leaching products, and these are proposed as responsible for the passivation of chalcopyrite. The presence of $\mathrm{CuS}_{2}$ was observed in the tests at 25 and $50^{\circ} \mathrm{C}$.

Author Contributions: Conceptualization, V.Q., A.R., O.B., and M.C.; methodology, V.Q., A.R., and M.C.; software, V.Q.; validation, A.R., O.B., and M.C.; formal analysis, E.M.; investigation, V.Q.; resources, A.R. and M.C.; data curation, M.C.; writing-original draft preparation, V.Q.; writingreview and editing, A.R., O.B., M.C., and E.M.; visualization, E.M.; supervision, A.R.; project administration, A.R.; funding acquisition, A.R. and M.C. All authors have read and agreed to the published version of the manuscript.

Funding: This research received no external funding.

Data Availability Statement: Not applicable.

Acknowledgments: The authors thank the Universitat de Barcelona and the Universidad Católica del Norte for the opportunity and funding provided to conduct this research. We also appreciate the contribution of the Scientific Equipment Unit-MAINI at the Universidad Católica del Norte for support in preparing samples, analysis, and data generation with QEMSCAN. We also thank the Centres Científics I Tecnològics, Universitat de Barcelona for their support in the application of characterization techniques. 
The authors thank the Canadian Institute of Mining, Metallurgy, and Petroleum (CIM) for the document "Effect of Curing Time on Copper Leaching from Chalcopyrite" from the Proceedings of the 58th Conference of Metallurgists Hosting Copper 2019, partially reprinted with permission of the CIM.

Conflicts of Interest: The authors declare no conflict of interest.

\section{References}

1. Ghorbani, Y.; Kuan, S.H. A review of sustainable development in the Chilean mining sector: Past, present and future. Int. J. Min. Reclam. Environ. 2017, 31, 137-165. [CrossRef]

2. Cánovas, M.; Valenzuela, J.; Romero, L.; González, P. Characterization of electroosmotic drainage: Application to mine tailings and solid residues from leaching. J. Mater. Res. Technol. 2020, 9, 2960-2968. [CrossRef]

3. Valenzuela-Elgueta, J.; Cánovas, M.; García, A.; Zárate, R. Electrocoalescence of emulsions in raffinate from the solvent extraction phase under AC electrical fields. J. Mater. Res. Technol. 2020, 9, 490-497. [CrossRef]

4. Cochilco. Proyección de la Producción de Cobre en Chile 2019-2030; Comunicaciones Cochilco: Santiago, Chile, 2019.

5. Zhao, H.; Zhang, Y.; Zhang, X.; Qian, L.; Sun, M.; Yang, Y.; Zhang, Y.; Wang, J.; Kim, H.; Qiu, G. The dissolution and passivation mechanism of chalcopyrite in bioleaching: An overview. Miner. Eng. 2019, 136, 140-154. [CrossRef]

6. Benavente, O.; Hernández, M.C.; Melo, E.; Núñez, D.; Quezada, V.; Zepeda, Y. Copper Dissolution from Black Copper Ore under Oxidizing and Reducing Conditions. Metals 2019, 9, 799. [CrossRef]

7. Quezada, V.; Benavente, O.; Beltrán, C.; Díaz, D.; Melo, E.; García, A. Dissolution of Black Copper Oxides from A Leaching Residue. Metals 2020, 10, 1012. [CrossRef]

8. Beiza, L.; Quezada, V.; Melo, E.; Valenzuela, G. Electrochemical Behaviour of Chalcopyrite in Chloride Solutions. Metals 2019, 9, 67. [CrossRef]

9. Wang, S. Copper leaching from chalcopyrite concentrates. JOM 2005, 57, 48-51. [CrossRef]

10. Nicol, M.J. Hydrometallurgy The anodic behaviour of chalcopyrite in chloride solutions: Overall features and comparison with sulfate solutions. Hydrometallurgy 2017, 169, 321-329. [CrossRef]

11. Dutrizac, J.E. Elemental sulphur formation during the ferric chloride leaching of chalcopyrite. Hydrometallurgy 1990, 23, 153-176. [CrossRef]

12. Nicol, M.; Zhang, S. Hydrometallurgy The anodic behaviour of chalcopyrite in chloride solutions: Potentiostatic measurements. Hydrometallurgy 2017, 167, 72-80. [CrossRef]

13. Lv, C.; Wu, H.; Lin, W.; Illerup, J.B.; Karcz, A.P.; Ye, S.; Damø, A.J. Characterization of elemental sulfur in chalcopyrite leach residues using simultaneous thermal analysis. Hydrometallurgy 2019, 188, 22-30. [CrossRef]

14. Lundström, M.; Aromaa, J.; Forsén, O.; Hyvärinen, O.; Barker, M.H. Leaching of chalcopyrite in cupric chloride solution. Hydrometallurgy 2005, 77, 89-95. [CrossRef]

15. Viñals, J.; Roca, A.; Hernández, M.C.; Benavente, O. Topochemical transformation of enargite into copper oxide by hypochlorite leaching. Hydrometallurgy 2003, 68, 183-193. [CrossRef]

16. Dutrizac, J.E. The leaching of sulphide minerals in chloride media. Hydrometallurgy 1992, 29, 1-45. [CrossRef]

17. Gok, O.; Anderson, C.G. Dissolution of low-grade chalcopyrite concentrate in acidified nitrite electrolyte. Hydrometallurgy 2013, 134, 40-46. [CrossRef]

18. Hernández, P.C.; Dupont, J.; Herreros, O.O.; Jimenez, Y.P.; Torres, C.M. Accelerating copper leaching from sulfide ores in acid-nitrate-chloride media using agglomeration and curing as pretreatment. Minerals 2019, 9, 250. [CrossRef]

19. Adebayo, A.O.; Sarangi, K. Separation of copper from chalcopyrite-Ammoniacal leach liquor containing copper, zinc, and magnesium by supported liquid membrane. Chem. Biochem. Eng. Q. 2011, 25, 309-316.

20. Moyo, T.; Petersen, J.; Nicol, M.J. The electrochemistry and kinetics of the oxidative dissolution of chalcopyrite in ammoniacal solutions: Part I-Anodic Reactions. Hydrometallurgy 2018, 182, 97-103. [CrossRef]

21. Moyo, T.; Petersen, J.; Nicol, M.J. The electrochemistry and kinetics of the oxidative dissolution of chalcopyrite in ammoniacal solutions. Part II-Cathodic reactions. Hydrometallurgy 2019, 184, 67-74. [CrossRef]

22. Baba, A.A.; Ghosh, M.K.; Pradhan, S.R.; Rao, D.S.; Baral, A.; Adekola, F.A. Characterization and kinetic study on ammonia leaching of complex copper ore. Trans. Nonferrous Met. Soc. China 2014, 24, 1587-1595. [CrossRef]

23. Petersen, J.; Dixon, D.G. Thermophilic heap leaching of a chalcopyrite concentrate. Miner. Eng. 2002, 15, 777-785. [CrossRef]

24. Petersen, J.; Dixon, D. Principles, mechanisms and dynamics of chalcocite heap bioleaching. Microb. Process. Met. Sulfides 2007, 193-218. [CrossRef]

25. Tanne, C.K.; Schippers, A. Electrochemical investigation of chalcopyrite (bio)leaching residues. Hydrometallurgy 2019, 187, 8-17. [CrossRef]

26. Tao, J.; Liu, X.; Luo, X.; Teng, T.; Jiang, C.; Drewniak, L.; Yang, Z.; Yin, H. An integrated insight into bioleaching performance of chalcopyrite mediated by microbial factors: Functional types and biodiversity. Bioresour. Technol. 2021, 319, 124219. [CrossRef] [PubMed]

27. Brierley, C.L.; Brierley, J.A. Progress in bioleaching: Part B: Applications of microbial processes by the minerals industries. Appl. Microbiol. Biotechnol. 2013, 97, 7543-7552. [CrossRef] 
28. Velásquez Yévenes, L. The Kinetics of the Dissolution of Chalcopyrite in Chloride Media. Ph.D. Thesis, Murdoch University, Murdoch, Australia, 2009.

29. Rauld, J.; Aroca, F.; Montealegre, R.; Backit, A. Procedure to Leach Copper Concentrates, Under Pressure and at Ambient Temperature, by Forming a Reactive Gel in Sulfate-Chloride Medium. U.S. Patent 7491372B2, 13 February 2009.

30. Aroca, F.; Backit, A.; Jacob, J. CuproChlor ${ }^{\circledR}$, a hydrometallurgical technology for mineral sulphides leaching. In Proceedings of the 4th International Seminar on Process Hydrometallurgy, Santiago, Chile, 11-13 July 2012; pp. 98-110.

31. Cerda, C.; Taboada, M.; Jamett, N.; Ghorbani, Y.; Hernández, P. Effect of Pretreatment on Leaching Primary Copper Sulfide in Acid-Chloride Media. Minerals 2017, 8, 1. [CrossRef]

32. Velásquez-Yévenes, L.; Quezada-Reyes, V. Influence of seawater and discard brine on the dissolution of copper ore and copper concentrate. Hydrometallurgy 2018, 180, 88-95. [CrossRef]

33. Quezada, V.; Velásquez, L.; Roca, A.; Benavente, O.; Melo, E.; Keith, B. Effect of curing time on the dissolution of a secondary copper sulphide ore using alternative water resources. In Proceedings of the IOP Conference Series: Materials Science and Engineering, Zawiercie, Poland, 26-29 September 2018; Volume 427. [CrossRef]

34. Dhawan, N.; Safarzadeh, M.S.; Miller, J.D.; Moats, M.S.; Rajamani, R.K. Crushed ore agglomeration and its control for heap leach operations. Miner. Eng. 2013, 41, 53-70. [CrossRef]

35. Lu, J.; Dreisinger, D.; West-Sells, P. Acid curing and agglomeration for heap leaching. Hydrometallurgy 2017, 167, 30-35. [CrossRef]

36. Quezada, V.; Roca, A.; Benavente, O.; Cruells, M.; Keith, B.; Melo, E. Effect of pretreatment prior to leaching on a chalcopyrite mineral in acid media using $\mathrm{NaCl}$ and $\mathrm{KNO}_{3}$. J. Mater. Res. Technol. 2020, 9, 10316-10324. [CrossRef]

37. Bai, X.; Wen, S.; Liu, J.; Lin, Y. Response surface methodology for optimization of copper leaching from refractory flotation tailings. Minerals 2018, 8, 165. [CrossRef]

38. Gnanavel, M.; Lebedev, O.I.; Bazin, P.; Raveau, B.; Pralong, V. Reversible transformation from amorphouse $\mathrm{Na}_{3} \mathrm{Fe}_{3}\left(\mathrm{SO}_{4}\right)_{2}\left(\mathrm{OH}_{6}\right.$ to crystallized $\mathrm{NaFe}_{3}\left(\mathrm{SO}_{4}\right)_{2}(\mathrm{OH})_{6}$ Jarosite-type hydroxysulfate. Solid State Ionics 2015, 278, 38-42. [CrossRef]

39. Zhong, S.; Li, Y. An improved understanding of chalcopyrite leaching kinetics and mechanisms in the presence of NaCl. J. Mater. Res. Technol. 2019, 8, 3487-3494. [CrossRef]

40. Elsherief, A.E. The influence of cathodic reduction, $\mathrm{Fe}^{2+}$ and $\mathrm{Cu}^{2+}$ ions on the electrochemical dissolution of chalcopyrite in acidic solution. Miner. Eng. 2002, 15, 215-223. [CrossRef]

41. Velásquez-Yévenes, L.; Nicol, M.; Miki, H. The dissolution of chalcopyrite in chloride solutions: Part 1. The effect of solution potential. Hydrometallurgy 2010, 103, 108-113. [CrossRef]

42. Lu, Z.Y.; Jeffrey, M.I.; Lawson, F. Effect of chloride ions on the dissolution of chalcopyrite in acidic solutions. Hydrometallurgy 2000, 56, 189-202. [CrossRef]

43. Guy, S.; Broadbent, C.P. Formation of copper (I) sulphate during cupric chloride leaching on a complex Cu/Zn/Pb ore. Hydrometallurgy 1983, 11, 277-288. [CrossRef]

44. Veloso, T.C.; Peixoto, J.J.M.M.; Pereira, M.S.; Leao, V.A. Kinetics of chalcopyrite leaching in either ferric sulphate or cupric sulphate media in the presence of $\mathrm{NaCl}$. Int. J. Miner. Process. 2016, 148, 147-154. [CrossRef]

45. Velásquez-Yévenes, L.; Miki, H.; Nicol, M. The dissolution of chalcopyrite in chloride solutions: Part 2: Effect of various parameters on the rate. Hydrometallurgy 2010, 103, 80-85. [CrossRef]

46. Quezada, V.A.; Roca, A.; Cruells, M.; Benavente, O.A. Effect of curing time on copper leaching from chalcopyrite. In Proceedings of the COM Hosting Copper 2019, Vancouver, BC, Canada, 18-21 August 2019; p. 11.

47. Jansen, M.; Taylor, A. Overview of gangue mineralogy issues in oxide copper heap leaching. In Proceedings of the ALTA Conference, Perth, Australia, 19-24 May 2003; p. 32.

48. Nicol, M.; Miki, H.; Zhang, S. The anodic behaviour of chalcopyrite in chloride solutions: Voltammetry. Hydrometallurgy 2017, 171, 198-205. [CrossRef]

49. Córdoba, E.M.; Muñoz, J.A.; Blázquez, M.L.; González, F.; Ballester, A. Passivation of chalcopyrite during its chemical leaching with ferric ion at $68^{\circ} \mathrm{C}$. Miner. Eng. 2009, 22, 229-235. [CrossRef]

50. Dutrizac, J.E. Factors affecting alkali jarosite precipitation. Metall. Trans. B 1983, 14, 531-539. [CrossRef]

51. Martins, F.L.; Patto, G.B.; Leão, V.A. Chalcopyrite bioleaching in the presence of high chloride concentrations. J. Chem. Technol. Biotechnol. 2019, 94, 2333-2344. [CrossRef]

52. Nava, D.; González, I. Electrochemical characterization of chemical species formed during the electrochemical treatment of chalcopyrite in sulfuric acid. Electrochim. Acta 2006, 51, 5295-5303. [CrossRef]

53. Majima, H.; Awakura, Y.; Hirato, T.; Tanakat, T. The leaching of chalcopyrite in ferric chloride and ferric sulfate solutions. Can. Metall. Q. 1985, 24, 283-291. [CrossRef] 